\title{
Investor's Overreaction to an Extreme Event: Evidence from the World Trade Center Terrorist Attack*
}

\author{
SOJUNG CAROL PARK \\ Seoul National University \\ Seoul, Korea
}

\begin{abstract}
This paper investigates whether investors overreacted to the World Trade Center terrorist attack, using insurers' stock returns. Short-term abnormal return reversals are observed after the 9/11 attack. The reversals may reflect the substantially increased uncertainty surrounding insurer stocks after the event, meaning that the price reactions are efficient risk adjustments. However, after controlling for the change in risk, I still find evidence of price reversals, which I attribute to investor overreaction. To bolster this claim, I provide cross-sectional evidence that reversals are stronger for insurers with higher information asymmetry, which have wider ex-ante bid-ask spreads and smaller numbers of analysts following. This result indicates that the reversals are likely due to behavioral biases.
\end{abstract}

Keywords: September 11, Overreaction Hypothesis, Uncertain Information Hypothesis, Information Asymmetry

* This paper is part of my dissertation at Wharton School, University of Pennsylvania. I would like to thank my advisor Neil A.Doherty for his helpful comments, suggestions, and guidance. I also appreciate the comments and suggestions from Gregory Nini, Scott Harrington, and Jean Lemaire. Financial supports from Samsung Scholarship Foundation, Bradley Foundation, and the Institute of Management Research at Seoul National University are gratefully acknowledged. Any errors are my own.

** Assistant Professor of Finance at College of Business Administration, Seoul National University. 1 Gwanak-ro, Gwanak-gu, Seoul, 151-916, Korea; Email: sojungpark@snu.ac.kr; Phone: +82-02-880-8085 


\section{INTRODUCTION}

Market efficiency is a continuous topic of debates in finance literature. While the majority believes in market efficiency, many researchers have reported market anomalies such as market over- and underreaction. Among the two anomalies, the market underreaction is relatively well documented, and thus, momentum is considered as a pricing factor in some studies. Responding to these findings, Barberis et al. (1998) develop a behavioral model explaining both the market over- and underreaction, based on psychology literature of Griffin and Tversky (1992), in which authors show that individuals overreact to salient and extreme signals and underreact to weak signals. The September 11 terrorist attack was one of the most extreme events in the US history. The stock market was unable to function normally, and the major exchanges were closed for a week after the 9/11 attacks. When the market reopened on September 17, it experienced an enormous price drop. The price change was the most severe in the insurance and airline industries, which experienced direct losses from the event. If an overreaction is relevant for stock market investors, as predicted in behavioral models, such overreactions should be evident in behavior following 9/11, a very salient and extreme event. In this paper, I investigate the existence of the market overreaction after the 9/11 terrorist attack, using insurance company stock returns.

This study is not the first study investigating the insurance companies' stock price reaction after the 9/11 attack. Cummins and Lewis (2003) and Doherty et al. (2003) examine the insurers' stock price reactions after the 9/11 attack and find that the market reaction was mostly consistent with their rational predictions. However, Cummins and Lewis (2003) also report one puzzling finding of abnormal return reversals. As can be seen in Fig. 1, insurers' stock price depreciated an average of $10 \%$ on September 17 th, and the price bounced back from the 6th day of trading. In addition to the price reversals, Fig. 1 also show abnormal return reversals. Although the return reversals could be interpreted as investors' overreaction, Brown et al. $(1988,1993)$ argue that some empirical evidence, which suggests over- or underreaction, actually reflects changes in risks created by the events that generated the price reactions, meaning that the price reactions are efficient risk adjustments. Following the terrorist attacks of $9 / 11$, it is quite 

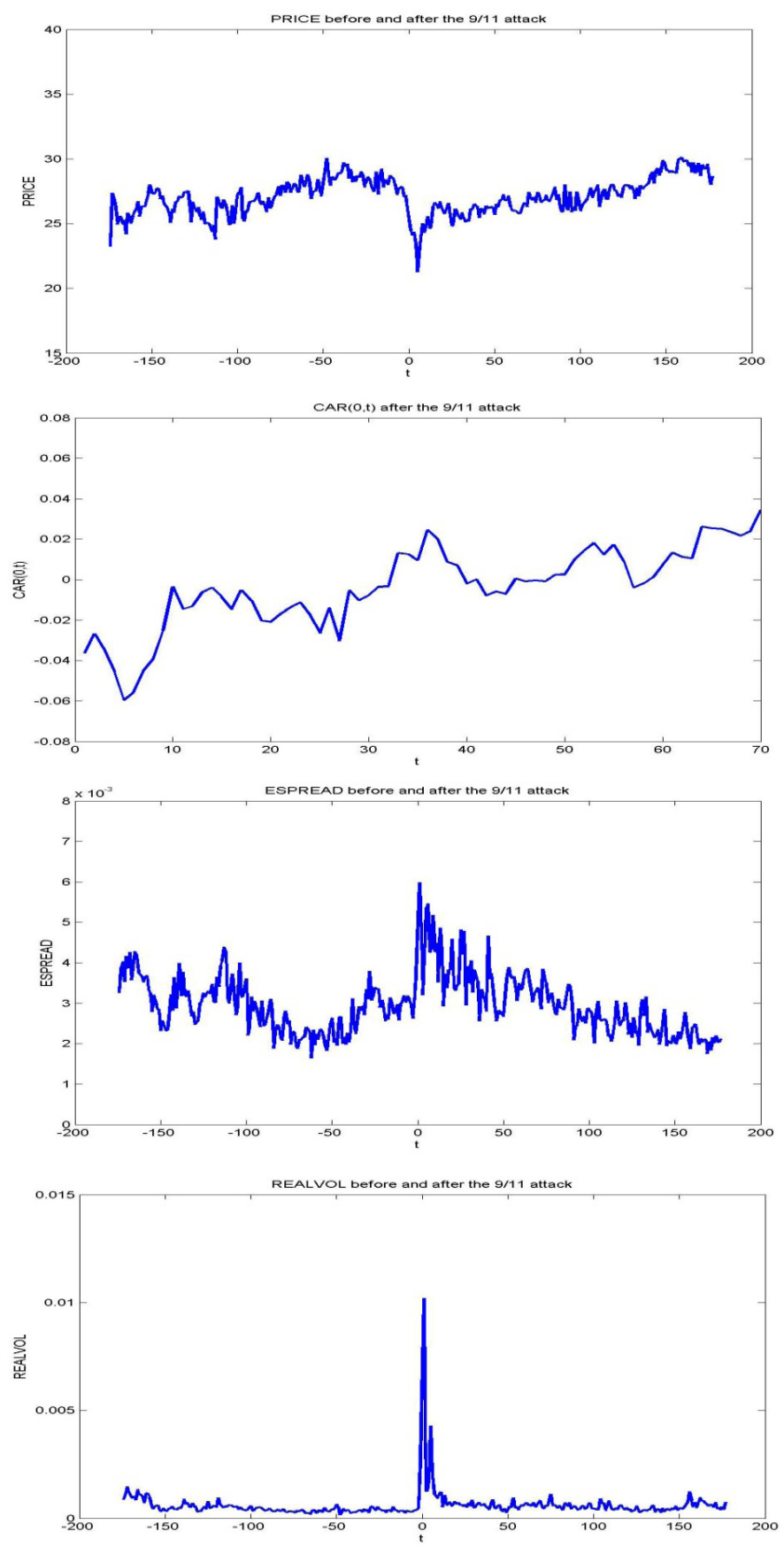

Fig. 1. Price, CAR, ESPREAD, and REALVOL before and after the 9/11 Attack 
likely that the uncertainty surrounding insurer stocks increased substantially. Drakos (2004), for example, finds structural shifts in systematic risk among airline stocks listed in various international stock markets. If the systematic risks of insurers really changed after the $9 / 11$, this could be the reason for the reversals observed in Cummins and Lewis (2003), because the abnormal returns in their study are computed with the market model parameters from a pre-shock estimation period. Therefore, I first test whether the systematic risks of insurers have changed before and after the 9/11 attack. Then, I estimate abnormal returns after the 9/11 attack using the post-shock parameter estimation period, in order to investigate whether the reversals can be attributed to changes in systematic risk or not. The results of this paper show that the systematic risks of insurers significantly increased but the return reversals still persist in the data after adjusting for the risk changes.

In order to bolster the claim that the reversals can be attributed to an overreaction, I provide cross sectional evidence that reversals are stronger for stocks with high information asymmetry. This argument is based on psychology and behavioral models; Griffin and Tversky (1992) show that the psychological bias is found to be stronger when individuals perform more difficult and uncertain tasks. Similarly, the model in Daniel et al. (1998) predicts stronger overor underreaction for the stocks with higher information asymmetry. Based on these models, Zhang (2006) constructs portfolios based on information uncertainty and finds evidence of stronger underreaction among the higher information uncertainty portfolios. Similar to Zhang (2006), I adapt information asymmetry proxies of the number of analysts following the stock and ex-ante bid-ask spreads, and examine differences in abnormal return reversals following the 9/11 attack. Consistent with the results in Zhang (2006) and the behavioral models, I find strong positive relationship between reversals and the information asymmetry proxies. In addition to the portfolio return comparison, I conduct cross-sectional regressions controlling for other factors that may influence the post 9/11 returns such as loss announcement and risk changes. The abnormal return is already adjusted for the systematic risk changes, but idiosyncratic risks also increased notably after the 9/11 attack. Although there are debates about the reason for which idiosyncratic risk appears to affect expected returns, there is substantial evidence that it does. For example, Barry and Brown (1985), Coles and 
Loewenstein (1988), Clarkson and Thompson (1990), and Coles et al. (1995) suggest 2 Refer to Daniel et al. (1998) for a list of studies reporting market underreaction. Fig. 1. Price, CAR, ESPREAD, and REALVOL before and after the 9/11 Attack that idiosyncratic risks may generate correlated parameter estimation risk. If changes in the risk are the sources of the observed reversals, we should find stronger reversals for insurers with larger changes in risks. I control for the risk changes using the daily realized volatility estimates computed with intraday data, as in Andersen et al. (2001, 2003) and daily implied volatility changes of insurance company stock options. The result of the regression analysis shows that the ex-ante level of information asymmetry is associated with the strength of reversals, after controlling for risk changes and loss announcement news. This finding indicates that the reversals are more likely due to the behavioral biases suggested in Griffin and Tversky (1992) and Barberis et al. (1998) than efficient risk adjustments.

This paper contributes to the finance literature in the following ways. Fama (1998) argues that the empirical findings of overreactions or underreactions cannot be evidence of market inefficiency because overreactions and underreactions are found at almost even chance. However, experimental evidence found in psychology literature and behavioral finance models suggest that overreactions and underreaction occurs under different occasions. One example is an overreaction to strong signals and an underreaction to weak signals. Although a body of literature reported momentum to various weak signals, post-event reversal to strong signal is rarely reported. Thus, the post-event overreaction result found in this paper provides supporting evidence for the market inefficiency arguments in behavioral finance literature.

The remainder of the paper is organized as follows. The following section discusses the related literature and develops testing hypotheses. Section 3 describes the sample data and methodology. Section 4 examines the stock price reactions to 9/11, compares the abnormal returns of information asymmetry portfolios, and conducts cross-sectional regressions. The final section concludes the paper. 


\section{RELATED LITERATURE AND HYPOTHESIS DEVELOPMENT}

\section{Hypotheses on Post-Shock Price Reactions}

The post 9/11 stock prices may have been impacted simultaneously by a number of factors. The following three hypotheses from the literature provide predictions for the post-shock stock price reactions.

\section{Investor Overreaction Hypothesis: Behavioral Models}

Barberis et al. (1998) adapt Griffin and Tversky's (1992) psychological model to explain the market price behavior. Griffin and Tversky show that people tend to be overconfident (underconfident) when "strength" is high (low) and "weight" is low (high). "Strength" means that news or signals are extreme and salient, and "weight" means statistical importance such as validity or reliability of news. Applying this psychological evidence to investment decisions in financial markets, Barberis et al. (1998) argue that investors underweigh low strength news in their Bayesian updating process. Therefore, they underreact to the low strength news such as a single earnings shock. This underreaction leads to a short-term price momentum.

On the other hand, investors overreact to a series of earnings shocks in the same direction, which can be considered as high strength news. The authors note that the empirical evidence of overreactions after high strength events are not yet well documented compared to the short-term momentums following earnings announcements, stock splits, or equity offerings. They point out that testing their model will be possible if there are ways to judge the strength of events a priori.

On the other hand, Daniel et al. (1998) argue that investors tend to be overconfident about private information and this overconfidence causes the overreactions. Prices increase (decrease) more than the real value changes when investors have positive (negative) signals from information leakage prior to public announcements. The overreacted price is eventually corrected as public information is released.

Daniel et al. also provide an empirical implication that the price reversals will be more significant for the firms with scarce public 
information. Besides from their private information based model, they also argue that any kind of mis-pricing such as reversals and momentums should be stronger among less liquid and high information asymmetry stocks because arbitragers face costs of collecting information, and thus, the arbitragers will first arbitrage away the profits from the stocks with better scales of economy: large and liquid stocks. The authors note that information asymmetry, which may be measured as an adverse selection component of bidask spreads, will be associated with market anomalies, such as momentum or reversal. Similarly, Griffin and Tversky (1992) also report evidence that psychological biases are severest for the tasks of highest difficulty.

The studies described above suggest an underreaction (momentum) after a low strength event and an overreaction (reversal) after a high strength event. Furthermore, the over- or underreactions will be severest in high information asymmetry stocks.

\section{Uncertain Information Hypothesis (UIH): Efficient Market Hypothesis}

While some suggest behavioral models to explain the reported market over- and underreactions, Brown et al. (1988, 1993) provide a different interpretation to these empirical findings. They contend that the transitory or permanent uncertainty increase (decrease) after major price innovations can lead to higher (lower) returns in an efficient market because an asset price is an expected sum of discounted risk-adjusted future payoffs in a no arbitrage world.

The September 11 terrorist attack was the largest man-made catastrophic event in the US insurance loss history. Even though the uncertainty about a war or terrorism was mostly resolved when the stock market reopened on September $17^{\text {th }}$, insurers still faced severe uncertainty increase about current and further terrorist attacks. Then, the increased uncertainty gradually reduced as market digested the news. If the increased uncertainty during this period were not totally diversifiable, the share price would have been affected accordingly. Therefore, this could appear to be an overreaction unless this risk change is not taken into account.

One possible source of undiversifiable risk change is a market beta shift. The equity beta instability has been documented in both theoretical and empirical researches. Galai and Masulis (1976), based on the Option Pricing model, show that unanticipated 
changes in the debt's term to maturity, the risk-free rate, the firm value, or the variance of the firm's return will change equity beta, and DeJong and Collins (1985) empirically support this model. In addition, Brown et al. (1998) find that events induce beta changes, and Drakos (2004) shows a significant structural systematic risk break before and after the 9/11 among airline stocks. Therefore, the betas of insurance stocks are likely to have changed due to the 9/11 loss shock. Failure to adjust this shift may result in an illusive abnormal return reversal. This beta change can be adjusted by using a post 9/11 market model parameter estimation period to compute the abnormal returns.

Kalay and Loewenstein (1985) suggest that there remains undiversifiable risk increase even after the beta shift adjustment. They argue that the undiversifiable risk during the event period is higher than normal since the potential of information release is high. This argument is supported in several researches. (eg. Kalay and Lewenstein,1985; Bhagat, Brickley, and Loewenstein, 1987). In addition, Barry and Brown (1985), Coles and Lowenstein (1988), Coles et al. (1995), and Clarkson and Thompson (1990) suggest that parameter estimation risk may not be diversifiable either. Although there are some difference between model set-ups and conclusions, the studies commonly suggest that the parameter estimation risk changes the perceived market beta, thereby influencing the returns under the Savage extension of the von Neumann-Morgenstern axioms. ${ }^{1)}$

\section{Empirical Implications from the Hypotheses}

The main empirical implication of the overreaction hypothesis is that if investors overreacted to the 9/11 event news, they should have overreacted more for the high information asymmetry firms. On the other hand, the uncertain information hypothesis argues that the price movements are affected by uncertainty changes. Thus, the stock prices will be associated with the degree of uncertainty changes during the post 9/11 period, not the level of information

1) Barry and Brown (1985) show that the parameter estimation risk is undiversifiable only when the information uncertainty is asymmetry across firms in financial market, but Coles and Lowenstein and Coles et al. show that the risk is not diversifiable in the symmetric case as well. 
asymmetry.

The empirical verification might not be successful if, for some reasons or by chance, the uncertainty change after the shock is systematically greater for opaque firms. In order to explore this possibility, I first check the correlations between the information asymmetry proxies and the uncertainty change proxies. The uncertainty changes are also controlled when testing the association between the abnormal return reversal and information asymmetry in the regression models.

\section{Information Asymmetry and Uncertainty Change Proxies}

Testing the hypotheses requires proxies for information asymmetry and uncertainty changes. One natural proxy for information asymmetry is a firm size. Large public firms are likely to have more public information available; they have more consumers, shareholders, and business partners; credit rating agencies and earning analysts cover large firms more than small firms; information acquisition costs may be lower for large firms.

The number of analysts following a firm can be a proxy for the information asymmetry. Analysts combine and release information to public, thereby reducing the information gap between insiders and outsiders as well as the information asymmetry between traders. There is also empirical evidence on the association between the number of analysts following a firm and the information asymmetry (Brennan and Subrahmanyam, 1995; Lang and Lundholm, 1996; Gleason and Lee, 2003). In testing the investors'

underreactions, Zhang (2006) also adapts the number of analysts following as a proxy for information uncertainty.

Another information asymmetry proxy used in this study is a bidask spread. The bid-ask spread can provide additional information to the size or analyst coverage; because the daily change of spreads is observable, the information asymmetry change around the 9/11 can be measured. This study uses the following daily average effective spreads as a proxy for information asymmetry.

For an uncertainty change, I employ the realized volatility developed in Andersen et al. $(2001,2003)$ as a proxy for a daily uncertainty. According to their work, the realized volatility using intraday returns is more efficient estimator than a daily return volatility. This study uses an interpolated procedure developed in 
Andersen et al. (2001) to generate five-minute return series.

The usage of high frequent intraday trading data allows the daily volatility observable. Fig. 1 shows the volatility change around the 9/11. As expected, the volatility increases on September $17^{\text {th }}$, then gradually decreases for the following two to three months. Even though the realized volatility does not measure the undiversifiable risk but captures the daily volatility, it is still plausible to assume that the more the total uncertainty changes, the more undiversifiable risk, such as parameter estimation risk, changes. ${ }^{2), 3)}$

\section{DATA AND METHODOLOGY}

\section{Data}

The initial data set is drawn from Compustat and CRSP (Center for Research in Securities Prices). Firms that are traded on the NYSE, AMEX, or NASDAQ, have SIC codes identify them as propertycasualty insurance companies (SIC code: 6331) or life-health companies (SIC code: 6311, 6321), and have a trading record for the entire year of 2001 are collected. This initial sample is matched with the NAIC (National Association of Insurance Commissioners) and TAQ (Trade and Quote) databases using ticker, company names, licensed states, and subsidiary information. Following previous literature using bid-ask spread, I exclude firms with average annual share price less than $\$ 1$ or greater than $\$ 400$. I also exclude firms that have less than 400 trading per year. The final sample includes

2) Brown et al. (1993) and Bhagat et al. (1987) also use a daily return standard deviation change as a proxy for a risk change. Barry and Brown (1985) and Clarkson and Thompson (1990) employ the number of trading days as a proxy for the parameter estimation risk. However, since the number of trading days after the systematic risk change is the same for all sample companies, this proxy is inappropriate for the purpose of this study.

3) In addition to the realized volatility, I adapt a daily option implied volatility changes as a proxy for the uncertainty changes. Since the stock price reflects expected future cash flows and expected risk, it is more appropriate to control for the expected risk changes than realized risk changes. Option implied volatility reflects the expected volatility by definition. However, I use the realized volatility changes in the main regression analyses because only a limited number of stocks have the option volatility data. Using option implied volatility does not change the results. Results available upon request. 
82 insurance companies. The names of the companies in the sample are listed in the Appendix.

Intraday trade and quote data from TAQ are obtained to compute the bid-ask spreads and realized volatilities. Option implied volatilities are collected from OptionMetrics. CRSP tapes provide other financial information, such as stock returns. Annual firmspecific accounting data and quarterly firm-specific accounting data are obtained from the NAIC and COMPUSTAT, respectively. In addition to the financial data, Best's insurance company credit rating is obtained from the Best's Insurance Reports, and the estimated net loss announcement after the 9/11 data are manually collected from Morgan Stanley's Insurance and Risk Briefing and Factiva.com.

\section{Event Study: Abnormal Returns and Cumulative Abnormal Returns}

To measure the stock price reaction to the $9 / 11$ event, the standard market-adjusted event-study methodology is used. The abnormal return (AR) and the cumulative abnormal return (CAR) are defined as follows.

$$
\begin{aligned}
& A R_{i t}=R_{i t}-\hat{\alpha}-\hat{\beta} R_{m t} \\
& C A R_{i}\left(\tau_{1}, \tau_{2}\right)=\sum_{\tau_{1}}^{\tau_{2}} A R_{i t}
\end{aligned}
$$

where $R_{i t}$ is a stock i's return on day t; $R_{m t}$ is the return of the CRSP value-weighted market index on day t; $\hat{\alpha}_{i}$ and $\hat{\beta}_{i}$ are the market parameter estimates $\alpha_{i}$ and $\beta_{i}$ obtained from the following market model,

$$
R_{i t}=\alpha_{i}+\beta_{i} R_{m t}+\varepsilon_{i t}
$$

using 250 day stock returns from the $260^{\text {th }}$ day to the $11^{\text {th }}$ day before September $11^{\text {th }}$ (i.e., Event Window $(-260,-11)$ ). Since the uncertain information hypothesis implies a possible change in the systematic risk of a firm after the shock, $A R_{i t}$ is also estimated for the post-shock estimation period of $(61,310){ }^{4}{ }^{4}$

4) A 200 or 250 day estimation period is conventional in event-study literature. The 
Three methodologies are used to test the statistical significance of abnormal and cumulative abnormal returns that are different from zero during the event period: a standard market model, a crosssectional model, and multivariate regression model. Although it is the most widely used test, the standard market model methodology is known to over-reject the null hypothesis in the presence of crosssectional dependence, and the testing power is lowered when the variance increases during the event period. Since the sample firms in this study are all in the same industry and the event date is also the same as the calendar date, the model will reject the null hypothesis too often. Furthermore, the increased variance of the stock return will also reduce the power of the standard model. Therefore, in order to adjust the increased variance factor, the crosssectional model testing methodology is also adapted. However, one of the important assumptions of the cross-sectional model is the cross-sectional independence, which is not very likely in the sample of this study. Thus, the multivariate regression methodology used in Binder (1985), which allows cross-sectional dependence, is also used and described below.

The GLS methodology in Binder (1985) is an application of Zeller's Seemingly Unrelated Regression (SUR). Each security has the following return generating model.

$$
R_{i t}=\alpha_{i}+\beta_{i} R_{m t}+\sum_{k=1}^{3} \gamma_{i k} D_{k}+\varepsilon_{i t}
$$

where $D_{k}$ is a dummy variable equal to one on the event day $\mathrm{k}$ and zero otherwise. By estimating this model in systemic SUR type equations, the model allows the disturbance to have crosssectional dependence and different variances for each firm. In order to overcome the possibility of the nonsynchronous trading, I include the lead and lag of market returns in the regression model

post-shock estimation period of $(61,310)$ is selected to avoid the overlapping of the estimation period and the event period. In fact, the market model parameter estimates using $(11,260)$ and $(61,310)$ are not significantly different. The mean beta estimates using $(6,60)$ and $(61,310)$ estimation period are presented in Table 2.

5) In addition to these three model, I also used Fama-French three factor model and Cahart's four factor model as robustness checks. Results does not vary. Results are available upon request. 
like Cornett and Tehrania (1990) and $\beta_{i}^{\prime} D_{0} R_{m t}$ to adjust the possible systemic risk change beta after the shock as is done in Carter and Simkins (2004). The final modified multivariate regression model is as follows.

$$
\begin{aligned}
R_{i t}= & \alpha_{i}+\beta_{1 i} R_{m, t-1}+\beta_{2 i} R_{m, t}+\beta_{3 i} R_{m, t+1}+\beta_{1 i}^{\prime} D_{0} R_{m, t-1} \\
& +\beta_{2 i}^{\prime} D_{0} R_{m, t}+\beta_{3 i}^{\prime} D_{0} R_{m, t+1}+\sum_{k=1}^{3} \gamma_{i k} D_{k}+\varepsilon_{i t}
\end{aligned}
$$

where $D_{0}$ is a dummy equal to 1 for the post shock period, $D_{1}$ is a dummy for the first day of trading after the shock, $D_{2}$ is a dummy for the first week of trading, and $D_{3}$ is a dummy for the second week to 60th trading days. The null hypothesis for the abnormal return is

$$
H 1: \quad \gamma_{1 k}=\gamma_{2 k}=\ldots=\gamma_{N k}=0
$$

In addition to the SUR estimation, I constructed an equally weighted insurance stock portfolio and applied the following regression model.

$$
\begin{aligned}
R_{p t}= & \alpha_{p}+\beta_{1 p} R_{m, t-1}+\beta_{2 p} R_{m, t}+\beta_{3 p} R_{m, t+1}+\beta_{1 p}^{\prime} D_{0} R_{m, t-1} \\
& +\beta_{2 p}^{\prime} D_{0} R_{m, t}+\beta_{3 p}^{\prime} D_{0} R_{m, t+1}+\sum_{k=1}^{3} \gamma_{p k} D_{k}+\varepsilon_{p t}
\end{aligned}
$$

The null hypothesis for abnormal return is

$$
H 2: \gamma_{p k}=0
$$

The equations of (15) and (16) are estimated using returns for the period including 50 days of pre-shock trading days and 200 days of post-shock trading days.

\section{Information Asymmetry Portfolio Return Comparison}

If we still find reversals after the adjustments to the new betas, this may be attributed to the overreactions. In order to strengthen this argument, I test the cross-sectional implication predicted by the overreaction hypothesis: stronger reversals among high information asymmetry stocks. In order to examine this, I construct three information asymmetry portfolios based on the information 
asymmetry proxies and compare the abnormal returns.

The first set of portfolios is constructed using the number of analysts following as a proxy of information asymmetry. If the number of analysts following during year 2001 was greater or equal to ten, the stock is assigned to a low information asymmetry portfolio. Stocks with less than three analysts are assigned to a high information asymmetry portfolio.

The other stocks are assigned to a medium portfolio. The second set is constructed similarly using the average effective spreads of the $(-260,-11){ }^{6)}$ The shares with ESPREAD in the upper $25 \%$ quartile and in the lower $25 \%$ quartile are assigned to high information asymmetry and low information asymmetry portfolio, respectively.

I first compare the information asymmetry portfolios' abnormal returns of first trading day $(\mathrm{AR}(1))$, the cumulative abnormal returns of the first week $(\mathrm{CAR}(2,5))$, and the cumulative abnormal returns between the second week to sixtieth trading day $(\operatorname{CAR}(6,60))$ to test the heterogeneous movement after the shock. I also apply the multivariate regression model methodology to the information asymmetry portfolios, and test whether the coefficient of the dummy variable for the first trading day in equation (5) is more negative and the coefficient of the dummy for the second week to sixtieth trading day is more positive for the high information asymmetry stocks than low information asymmetry stocks. The comparison of abnormal returns and the coefficients of multivariate regression model examine whether the stocks with higher information asymmetry experienced severer reversal or not. Finally, to strengthen this argument, I construct the following variables which directly measure a degree of reversal and test the reversal difference between high and low information asymmetry portfolios.

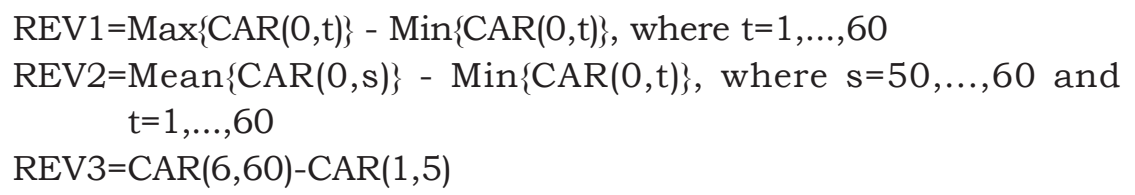

I assign 0 to REV1 and REV2 when the minimum occurs between

6) The pre-shock period average bid-ask spreads are used as a spurious relationship because the spreads can be systematically correlated with other factors such as loss estimates, which can also influence the abnormal returns. 


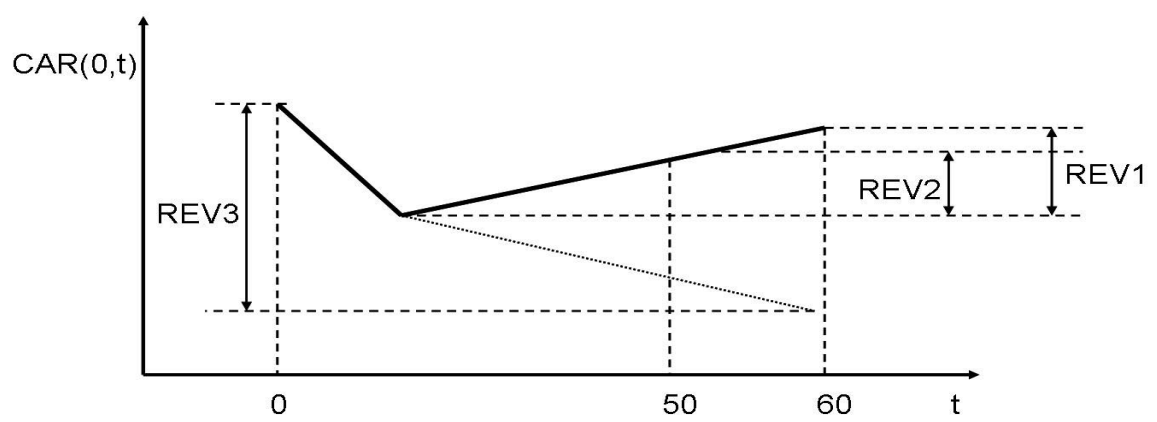

Fig. 2. Definition of Reversal Variables

$(50,60)$. The definition of these reversal variables are also depicted in Fig. 2. All three variables are designed to have larger values with stronger reversals.

\section{Cross-Sectional Regression Models}

In addition to the portfolio return comparison, I perform crosssectional regressions to control for other firm specific characteristics such as size, financial leverage, and rating. Four sets of regressions with $\operatorname{AR}(1), \operatorname{CAR}(2,5), \operatorname{CAR}(6,60)$, and reversal variables as dependent variables are performed. In order to resolve possible correlated crosssectional errors in the regression model, I construct an industry effect controlled abnormal returns from the following models.

$$
\begin{aligned}
& \operatorname{IAR}_{i t}=R_{i t}-\hat{\alpha}_{i}-\hat{\beta}_{1 i} R_{m t}-\beta_{2 i} \operatorname{Rind}_{i t} \\
& \operatorname{ICAR}_{i}\left(\tau_{1}, \tau_{2}\right)=\sum_{t=\tau_{1}}^{\tau_{2}} \operatorname{IAR} R_{i t}
\end{aligned}
$$

where Rind $_{i t}$ is an insurance industry return on day $t$. This industry index is an equally-weighted publicly traded insurance company stock return except the $i^{\text {th }}$ firm. Equal-weighted scheme is applied to form this index to avoid dominance of one large company when using value-weighted scheme and the $i^{\text {th }}$ firm is excluded from the construction of industry index for the $i^{\text {th }}$ regression model so as to avoid the contamination argued in Loughran and Ritter (2000). The abnormal returns from this market-industry model will reduce the correlation among residuals. 


\section{Short-term Reaction}

To test the cross-sectional return difference on the first day of trading after 9/11, I conduct a regression model with IAR(1) from the market-industry model and the $\gamma_{1}$ estimate from the multivariate regression model from equation (12) as dependent variables. The regression model of interest is:

$$
\begin{aligned}
\operatorname{IAR}(1)= & \delta_{1}+\delta_{2} I A+\delta_{3} E S C 1+\delta_{4} A S S E T+\delta_{5} C A P+\delta_{6} B E S T \\
& +\delta_{7} V O L C 1+\delta_{8} L O S S A+\delta_{9} L O S S P 1 \\
& +\delta_{10} L I N E+\delta_{11} R E I N S+\varepsilon
\end{aligned}
$$

where VOLC1 is the realized volatility difference between the first day of trading and the average of $(-90,-11)$; CAP is a financial leverage; LOSSP1 is the proportion of the announced net loss amount between September $11^{\text {th }}$ and $17^{\text {th }}$ to a quarter 2 asset; LOSSA is a dummy which equals one when there was a loss announcement between September $11^{\text {th }}$ and $17^{\text {th }}$ to a quarter 2 asset; LINE is the proportion of written premium of the lines of business that experienced major losses, such as Workers' Compensation; ASSET is the logged total asset; IA is the information asymmetry proxies described in the previous section; REINS is the proportion of unaffiliated reinsurance to a total asset; ESC1 is the increased effective spread on September $17^{\text {th }}$. Detailed variable definitions are prescribed in Table 1.

The overreaction hypothesis predicts a negative association between short-term abnormal returns and the level of information asymmetry. Therefore, ESPREAD (ANAL) will be negatively (positively) associated with $\mathrm{AR}(1)$. Although the spread on September $17^{\text {th }}$ may be a better proxy for the information asymmetry on the day than ESPREAD, the spread on September $17^{\text {th }}$ could be systematically correlated with other factors that can affect AR(1). For example, LINE can have a negative effect on AR(1) because firms with large LINE are likely to be hit by the 9/11 losses. At the same time, the uncertainty and information asymmetry may also have increased more for large LINE firms. Similarly, LOSSP1 will be negatively correlated with both $\mathrm{AR}(1)$ and the spread increase on September $17^{\text {th }}$ since the announcement will reduce the information asymmetry even though it is bad news. Therefore, in order to avoid this possibly spurious correlation, ESPREAD and ESC1 are included separately. 


\begin{tabular}{|c|c|c|c|c|c|c|c|c|c|c|c|}
\hline$\stackrel{\theta}{r}$ & $\begin{array}{l}\stackrel{0}{ } \\
\stackrel{\circ}{0} \\
\text { on }\end{array}$ & $\begin{array}{l}\text { ळे } \\
\text { Oे } \\
\text { - }\end{array}$ & $\begin{array}{l}\stackrel{\circ}{0} \\
\text { Oे } \\
\text { o }\end{array}$ & $\begin{array}{l}\infty \\
\sigma \\
\sigma \\
\infty \\
\infty\end{array}$ & $\begin{array}{l}\stackrel{0}{ } \\
\sigma \\
\infty \\
-1\end{array}$ & 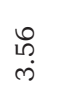 & \multicolumn{2}{|l|}{$\begin{array}{l}\infty \\
\infty \\
\infty\end{array}$} & $\begin{array}{l}\circ \\
0 \\
0 \\
0 \\
0\end{array}$ & \multicolumn{2}{|c|}{ 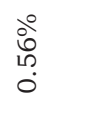 } \\
\hline 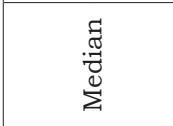 & $\begin{array}{l}\stackrel{\circ}{\wedge} \\
\stackrel{-1}{0}\end{array}$ & $\begin{array}{l}\stackrel{0}{0} \\
\infty \\
0 \\
\dot{1} \\
\dot{1}\end{array}$ & $\begin{array}{l}\stackrel{0}{\circ} \\
\overrightarrow{-} \\
\stackrel{0}{1}\end{array}$ & $\begin{array}{l}\hat{y} \\
0 \\
i \\
c\end{array}$ & $\begin{array}{l}\stackrel{0}{0} \\
\stackrel{\rho}{ } \\
\stackrel{\infty}{ }\end{array}$ & $\stackrel{N}{\sim}$ & \multicolumn{2}{|l|}{\llcorner} & $\begin{array}{l}\stackrel{0}{\circ} \\
\stackrel{1}{N} \\
o \\
0\end{array}$ & \multicolumn{2}{|l|}{$\begin{array}{l}\text { in } \\
\stackrel{0}{\circ}\end{array}$} \\
\hline $\begin{array}{l}\mathbb{\pi}^{\pi} \\
\sum_{\Sigma}^{\infty}\end{array}$ & $\begin{array}{l}\stackrel{0}{ } \\
\infty \\
10 \\
0\end{array}$ & $\begin{array}{l}\stackrel{0}{\circ} \\
\text { 广े } \\
\stackrel{0}{i} \\
\end{array}$ & $\begin{array}{l}\text { oे } \\
\text { ò } \\
\text { i. }\end{array}$ & $\begin{array}{l}\vec{a} \\
\overrightarrow{0} \\
\stackrel{0}{n}\end{array}$ & $\begin{array}{l}\stackrel{0}{ } \\
\vec{\lambda} \\
\text { ci }\end{array}$ & $\begin{array}{l}\underset{\infty}{+} \\
\stackrel{\sim}{\sim} \\
\sim\end{array}$ & \multicolumn{2}{|l|}{$\begin{array}{l}\stackrel{+}{\llcorner 0} \\
\infty \\
\infty\end{array}$} & $\begin{array}{l}\stackrel{\circ}{0} \\
\text { in. } \\
\text { Oे }\end{array}$ & \multicolumn{2}{|l|}{ 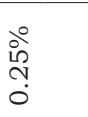 } \\
\hline \multirow{3}{*}{ 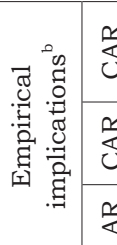 } & & & + & & & & ' & & I & + & \\
\hline & & + & & & & & & & & & \\
\hline & ' & & & + & + & + & + & + & ' & ' & ' \\
\hline 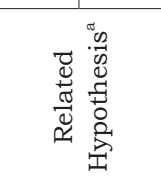 & 岕 & 岕 & 志 & 0 & U & O & 要 & U & \begin{tabular}{l|l} 
\\
\end{tabular} & 覀 & $\stackrel{Q 2}{\mu}$ \\
\hline 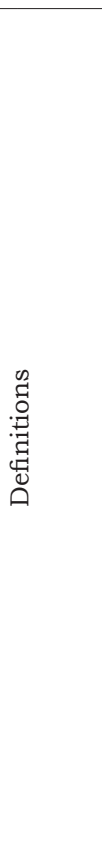 & 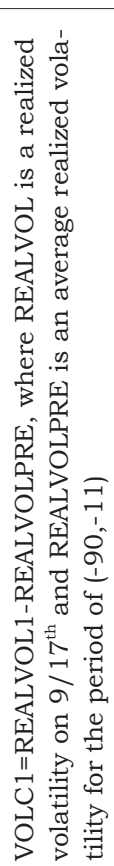 & 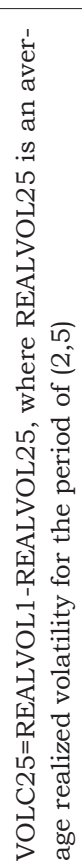 & 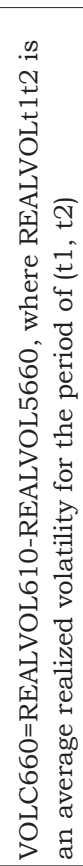 & 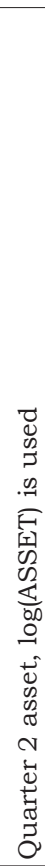 & 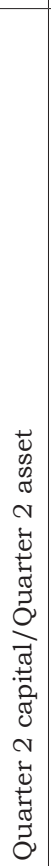 & 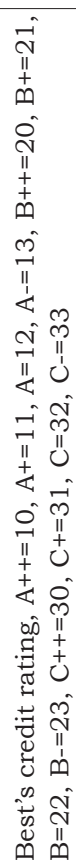 & 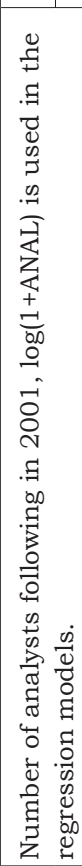 & & 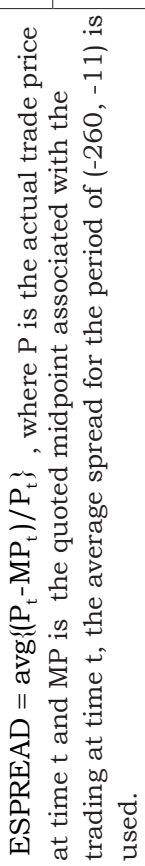 & 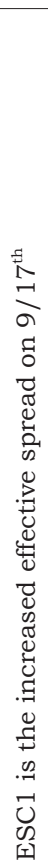 & \\
\hline 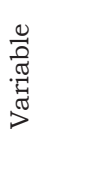 & $\begin{array}{l}\vec{U} \\
\stackrel{0}{O}\end{array}$ & $\begin{array}{l}\stackrel{L}{N} \\
\text { ] } \\
0 \\
>\end{array}$ & $\begin{array}{l}0 \\
0 \\
0 \\
0 \\
0 \\
> \\
>\end{array}$ & 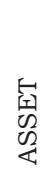 & 完 & $\begin{array}{l}5 \\
\text { 空 } \\
\text { 至 }\end{array}$ & 安 & & 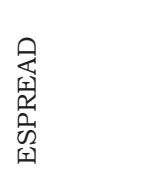 & $\begin{array}{l}\text { Un } \\
\text { II }\end{array}$ & \\
\hline
\end{tabular}




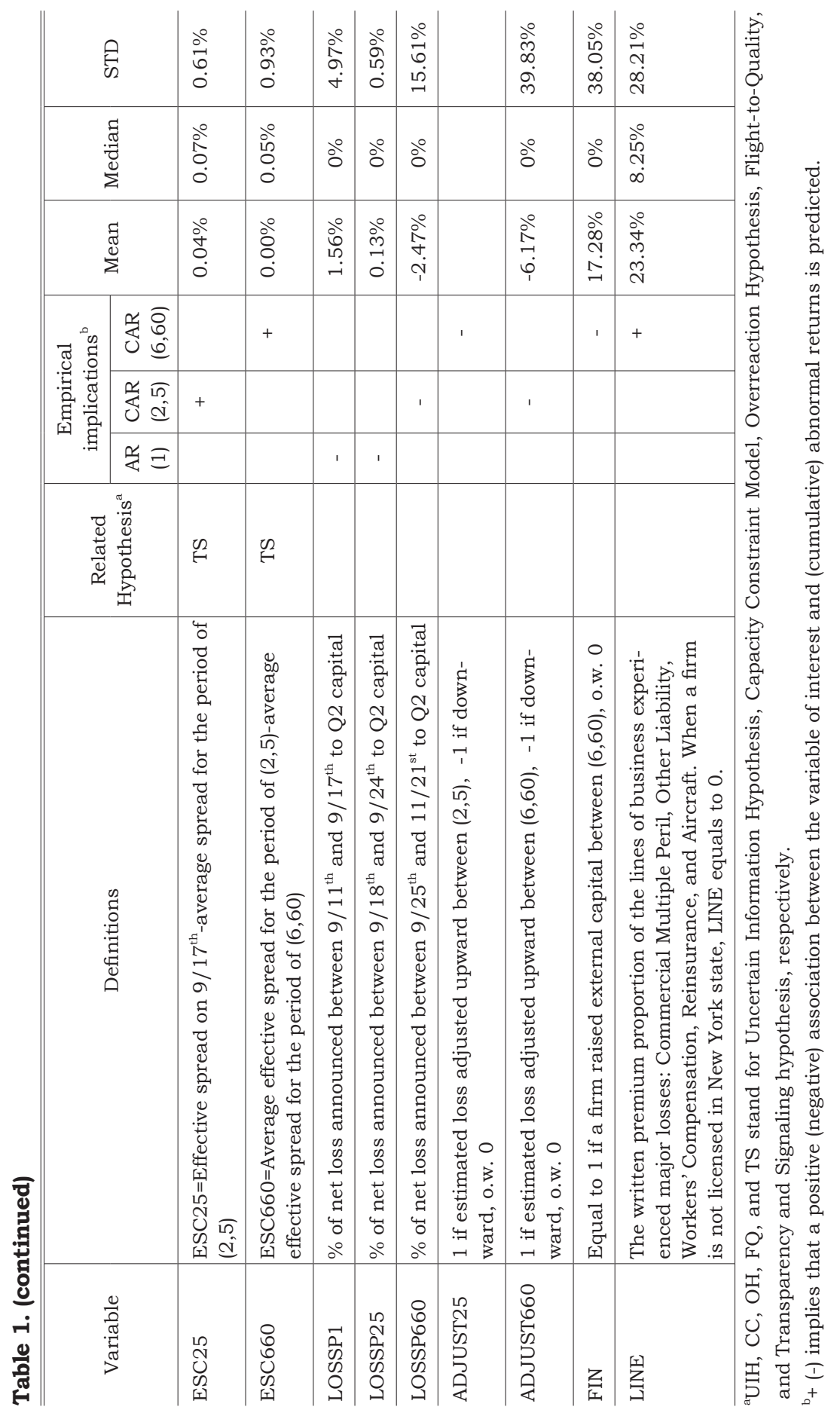


On the other hand, the uncertain information hypothesis predicts that the increased systematic risk has a negative effect on the first day return. In order to test the influence of the systematic risk change on the abnormal returns, the increased volatility -VOLC1- is included in the regression model.

BEST is added to the model because firms with good ratings may have earned better returns due to the flight-to-quality effect (an insurance demand in a post-event period tends to migrate to stronger firms), as reported in Cummins et al. (2003). The capacity constraint and principal agent model suggests that weakly capitalized firms have more negative abnormal returns on the first day of trading after the shock. Thus, CAP will be negatively associated with $\mathrm{AR}(1)$. The unaffiliated reinsurance, REINS, is added to the model in order to control the reinsurance company news impact during this period. LOSSP1 and LINE are included to control for the insurers' losses occurred from the 9/11 attack.

The coefficients of this model are estimated in the following Seemingly Unrelated Regression (SUR) model. Although none of the EQ2 and the EQ3 is the model of interest, the SUR estimation improves the estimation efficiency by allowing the errors of three equations to be correlated.

$$
\begin{aligned}
& \operatorname{IAR}(1)=\delta_{1}+\delta_{2} I A+\delta_{3} E S C 1+\delta_{4} A S S E T+\delta_{5} C A P \\
& \text { EQ1: } \quad+\delta_{6} B E S T+\delta_{7} \text { VOLC } 1+\delta_{8} L O S S A+\delta_{9} L O S S P 1 \\
& +\delta_{10} L I N E+\delta_{11} R E I N S+\varepsilon \\
& \text { EQ2: } \begin{aligned}
\text { VOLC1 }= & \kappa_{1}+\kappa_{2} A N A L+\kappa_{3} C A P+\kappa_{4} L O S S A \\
& +\kappa_{5} L I N E+\kappa_{6} R E I N S+\omega_{1}
\end{aligned} \\
& E Q 3: \begin{aligned}
E S C= & \varsigma_{1}+\varsigma_{2} A N A L+\varsigma_{3} C A P+\varsigma_{4} L O S S A 1 \\
& +\varsigma_{5} L I N E+\varsigma_{6} R E I N S+\omega_{2}
\end{aligned}
\end{aligned}
$$

Since uncertainty will increase more if a firm has losses, LOSSA and LINE are included in EQ2. The variables in EQ3 are chosen as the following reasons: when there are more analysts following a stock, the information asymmetry increase will be less, the information asymmetry of the firms with possible losses will increase more, but the increase is expected to be less for the firms which announced their losses. 


\section{Long-term Reaction}

In order to identify the negative association between the longterm abnormal return and the information asymmetry, the following regressions with $\operatorname{CAR}(2,5)$ and $\operatorname{CAR}(6,60)$ as dependent variables are performed. Like the short-term regression, SUR is performed to improve the estimation efficiency.

$$
\begin{aligned}
& \operatorname{ICAR}\left(\tau_{1}, \tau_{2}\right)=\delta_{1}+\delta_{2} I A+\delta_{3} E S C \tau_{1} \tau_{2}+\delta_{4} A S S E T+\delta_{5} C A P \\
& \text { EQ1 : } \quad+\delta_{6} B E S T+\delta_{7} V O L C \tau_{1} \tau_{2}+\delta_{8} L O S S A+\delta_{9} L O S S P \tau_{1} \tau_{2} \\
& +\delta_{10} A D J U S T \tau_{1} \tau_{2}+\delta_{11} F I N+\delta_{12} L I N E+\delta_{13} R E I N S+\varepsilon \\
& \text { EQ2: } V O L C \tau_{1} \tau_{2}=\kappa_{1}+\kappa_{2} I A+\kappa_{3} C A P+\kappa_{4} L O S S A \tau_{1} \tau_{2} \\
& +\kappa_{5} A D J U S T \tau_{1} \tau_{2}+\kappa_{6} \text { FIN }+\kappa_{7} L I N E+\kappa_{8} R E I N S+\omega_{1} \\
& \text { EQ3: } E S C \tau_{1} \tau_{2}=\varsigma_{1}+\varsigma_{2} I A+\varsigma_{3} C A P+\varsigma_{4} L O S S A \tau_{1} \tau_{2}+\varsigma_{5} A D J U S T \tau_{1} \tau_{2} \\
& +\varsigma_{6} F I N+\varsigma_{7} L I N E+\varsigma_{8} R E I N S+\omega_{2}
\end{aligned}
$$

where $\operatorname{VOLC} \tau_{1} \tau_{2}$ is the realized volatility change during $\left(\tau_{1}, \tau_{2}\right)$; $\operatorname{LOSSP} \tau_{1} \tau_{2}$ is an announced loss between $\tau_{1}$ and $\tau_{2} ; F I N \tau_{1} \tau_{2}$ is a dummy variable equal to 1 if a firm raises its external capital between $\tau_{1}$ and $\tau_{2}$, otherwise zero; $A D J U S T \tau_{1} \tau_{2}$ is a variable equal to 1 if a firm announces an increased loss re-estimate between $\tau_{1}$ and $\tau_{2}$, equal to -1 if the re-estimate is less than the original announcement, otherwise zero; $E S C \tau_{1} \tau_{2}$ is the reduced effective bid-ask spread. Detailed variable definitions are provided in Table 1.

First of all, the information factors, ESPREAD (ANAL) will have a positive (negative) association with the $C A R\left(\tau_{1}, \tau_{2}\right)$ if investors have overreacted. $\operatorname{LOSSP}_{1} \tau_{2}, F I N \tau_{1} \tau_{2}$, and $A D J U S T \tau_{1} \tau_{2}$ are added to the long-term reaction model in order to incorporate the new capital and loss information during the period over which the cumulative abnormal return is computed. $L O S S P \tau_{1} \tau_{2}$ and $A D J U S T \tau_{1} \tau_{2}$ will have a negative or positive effect depending on the difference between the announced losses and expected losses. $F I N \tau_{1} \tau_{2}$ is expected to have a positive coefficient because of the reduced agency problem and the expected profitability during the following hard market. $E S C \tau_{1} \tau_{2}$ will have a positive effect if investors reward the reduced information asymmetry. Finally, $\operatorname{VOLC} \tau_{1} \tau_{2}$ will have a positive association with $C A R\left(\tau_{1}, \tau_{2}\right)$ if the reversal is associated with the reduced uncertainty. 


\section{Reversals}

As is done in portfolio return comparison, I regress the three reversal variables of REV1, REV2, and REV3, on information asymmetry proxies and variables related with news announced during the 60 trading days after the 9/11 attack. The regression model is as follows.

$$
\begin{aligned}
\text { IREV }= & \delta_{1}+\delta_{2} \text { ESPREAD }+\delta_{3} 3 \text { LOSSA }+\delta_{4} \text { LOSSP1 } \\
& +\delta_{5} \text { LOSSP } 25+\delta_{6} \text { LOSSP660 }+\delta_{7} \text { ADJUST2 } 5 \\
& +\delta_{8} \text { ADJUST660 }+\delta_{9} \text { FIN }+\delta_{10} \text { REINS }+\delta_{11} \text { VOLMM }+\varepsilon
\end{aligned}
$$

where VOLMM is the difference between maximum daily realized volatility and minimum realized volatility for each stock during the sample period. VOLMM is included to control for uncertainty changes. It is possible that the degree of reversal seems to be larger simply because of more volatility during this after the shock period. Thus, I also use alternative uncertainty control of pre-shock average volatility level, VOLPRE, in the additional analysis to avoid this endogeneity problem.

The overreaction hypothesis predicts stronger reversal among high information asymmetry stocks, so positive relationship between REV and ESPREAD is predicted. Good news announced after the first day of trading will be associated with reversal. Therefore, positive coefficients are predicted for ADJUST25, ADJUST660, and FIN.

\section{RESULTS}

Table 1 presents descriptive statistics for the variables of interest. Panel A of Table 2 shows stock market trading reactions to the 9/11 attack. The effective spreads and realized volatilities increased, and then decreased to the pre-shock level, as expected. The daily movement of median effective spread and realized volatility of sample insurer stocks are depicted in Fig. 1.

Panel B of Table 2 provides the market beta, estimated from equation (4) using different estimation periods to examine the systematic risk changes before and after the shock. Consistent with the result in Drakos (2004), the market beta increased significantly after the shock. This significant increase implies that the abnormal 
Table 2. Descriptive Statistics

\section{Panel A. Stock Trading Behavior}

\begin{tabular}{|c|c|c|c|c|c|c|}
\hline \multirow[b]{2}{*}{ Variable } & \multirow[b]{2}{*}{ Statistic } & \multicolumn{5}{|c|}{ Sample period } \\
\hline & & $\begin{array}{l}\text { Pre shock } \\
(-260,-11)\end{array}$ & $\begin{array}{c}\text { September } \\
17^{\text {th }}\end{array}$ & $\begin{array}{c}\text { Post shock } \\
(2,5)\end{array}$ & $\begin{array}{c}\text { Post shock } \\
(6,60)\end{array}$ & $\begin{array}{c}\text { Post shock } \\
(61,310)\end{array}$ \\
\hline \multirow[t]{3}{*}{ RET } & Mean & $0.1191 \%$ & $-6.2612 \%$ & $-1.9751 \%$ & $0.3283 \%$ & $-0.0468 \%$ \\
\hline & Post-Pre & $\mathrm{N} / \mathrm{A}$ & $-0.0640 * * *$ & $-0.0212^{* * *}$ & $0.0019 * * *$ & $-0.0340 \%$ \\
\hline & Difference $^{7)}$ & & {$[-10.031]$} & {$[-9.4275]$} & [4.8262] & {$[-0.9207]$} \\
\hline \multirow[t]{3}{*}{ ESPREAD } & Mean & 0.5056 & 0.8418 & 0.7566 & 0.6664 & 0.4825 \\
\hline & Post-Pre & $\mathrm{N} / \mathrm{A}$ & $0.3361^{* * *}$ & $0.2510^{* * *}$ & $0.1608^{* * *}$ & -0.0230 \\
\hline & Difference & & [3.0343] & [3.5786] & [3.3599] & {$[-0.5302]$} \\
\hline \multirow[t]{3}{*}{ TVOLUME } & Mean & $331,357.19$ & $1,054,732.5$ & $715,223.4$ & $382,654.4$ & $406,823.89$ \\
\hline & Post-Pre & $\mathrm{N} / \mathrm{A}$ & $723,375.3^{* * *}$ & $387,025.3^{* * *}$ & $54,456.29 * *$ & $75,466.70^{* * *}$ \\
\hline & Difference & & [3.2357] & [2.6675] & [2.2503] & [3.3187] \\
\hline \multirow[t]{3}{*}{ REALVOL } & Mean & 0.1595 & 2.6051 & 0.7701 & 0.2374 & 0.1687 \\
\hline & Post-Pre & $\mathrm{N} / \mathrm{A}$ & $2.4457^{* * *}$ & $0.6106^{* * *}$ & $0.0779 * * *$ & 0.0092 \\
\hline & Difference & & [5.0937] & [4.4433] & [2.6709] & {$[0.2652]$} \\
\hline
\end{tabular}

Panel B. Beta Changes

\begin{tabular}{|c|c|c|c|c|c|}
\hline \multirow[b]{2}{*}{ Variable } & \multirow[b]{2}{*}{ Statistic } & \multicolumn{4}{|c|}{ Sample period } \\
\hline & & $\begin{array}{l}\text { Pre shock } \\
(-260,-11)\end{array}$ & $\begin{array}{c}\text { Post shock } \\
(1,5)\end{array}$ & $\begin{array}{c}\text { Post shock } \\
(6,60)\end{array}$ & $\begin{array}{c}\text { Post shock } \\
(61,310)\end{array}$ \\
\hline \multirow[t]{3}{*}{ BETA } & Mean & 0.3827 & 0.8376 & 0.6436 & 0.6537 \\
\hline & Post-Pre & $\mathrm{N} / \mathrm{A}$ & 0.4549 & 0.2609 & 0.2710 \\
\hline & Difference & & [8.3819] & [5.3677] & [8.4743] \\
\hline \multirow{3}{*}{$\begin{array}{l}\text { ADJUSTED } \\
\text { BETA }\end{array}$} & Mean & 0.3496 & 0.8445 & 0.6741 & 0.6038 \\
\hline & Post-Pre & $\mathrm{N} / \mathrm{A}$ & 0.4949 & 0.3245 & 0.2542 \\
\hline & Difference & & [7.5412] & [4.2038] & [5.4708] \\
\hline \multirow{3}{*}{$\begin{array}{l}\text { BETA } \\
\text { (frequently } \\
\text { traded } \\
\text { stocks only) }\end{array}$} & Mean & 0.4497 & 0.9549 & 0.8291 & 0.7681 \\
\hline & Post-Pre & $\mathrm{N} / \mathrm{A}$ & 0.5052 & 0.3794 & 0.3184 \\
\hline & Difference & & [7.9750] & [7.2535] & [7.7623] \\
\hline
\end{tabular}

7) Post-pre difference is the mean of corresponding post-shock period estimatespre-shock period estimates. Pair-wise t-test is conducted and the t-stats are presented in the parenthesis [ ] 
Table 2. (continued)

Panel C. Correlation Matrix of Information Asymmetry and Uncertainty Changes $^{8)}$

\begin{tabular}{c|c|c|c|c|c}
\hline \hline & ESPREAD & ANAL & VOLC1 & VOLC25 & VOLC660 \\
\hline ESPREAD & 1 & & & & \\
\hline ANAL & $\begin{array}{c}-0.4025^{* * *} \\
(0.0002)\end{array}$ & 1 & & & \\
\hline VOLC1 & -0.0322 & 0.1228 & 1 & & \\
& $(0.7782)$ & $(0.2809)$ & & & \\
\hline VOLC25 & 0.0010 & $-0.2233^{* *}$ & $-0.9303^{* * *}$ & 1 & \\
& $(0.9931)$ & $(0.0479)$ & $(0.0000)$ & & 1 \\
\hline VOLC660 & -0.1550 & 0.0574 & 0.1630 & -0.0924 & $(0.4210)$ \\
& $(0.1727)$ & $(0.6152)$ & $(0.1538)$ & & \\
\hline
\end{tabular}

* The null hypothesis is rejected at a significance level of $10 \%$, ** Idem, $5 \%$, *** Idem, $1 \%$.

returns estimated using the pre-shock estimation period could be biased. However, it is also possible that this estimated beta shift shows up not because of the systematic risk change, but because of the estimation bias occurred due to the nonsyncrous trading discussed in Sholes and Williams (1977). In fact, Table 2 shows that the trading volume increased significantly after the shock. Therefore, it is likely that the change in beta before and after the shock may be caused by the increased frequency of trading. To explore this possibility, I provide the Sholes and Williams (1977)'s unsyncronous trading adjusted beta estimates and the beta estimates of stocks with trading data every day during 2001 in the Table $2 .{ }^{9}$ The results show that all three beta estimates increased significantly.

Correlation coefficients between variables of interest are shown in Panel C. First of all, the two proxies of information asymmetry - the number of analysts following and the effective spreadare significantly correlated. The correlation coefficients between information asymmetry proxies and the uncertainty change proxy mitigate the concern about the identification. Both the uncertain

8) The Pearson correlation coefficients are presented. The numbers in the parentheses are the $\mathrm{p}$-values of the estimates

9) 26 stocks out of 82 do not have trading data everyday. 
Table 3. Abnormal Returns and Cumulative Abnormal Returns

Panel A: Abnormal returns and test statistics

\begin{tabular}{|c|c|c|c|}
\hline $\mathrm{t}$ & Abnormal Return & Standard Model & Cross-sectional Model \\
\hline & & $\theta_{1}$ & $\theta_{2}$ \\
\hline-5 & -0.0010 & -0.4136 & -0.3794 \\
\hline-4 & 0.0018 & 0.2611 & 0.2909 \\
\hline-3 & 0.0056 & $1.9488 * *$ & $2.3399 * *$ \\
\hline-2 & 0.0013 & -0.2752 & -0.3002 \\
\hline-1 & 0.0045 & $2.3310 * *$ & $2.2812^{*}$ \\
\hline 1 & -0.0309 & $-11.578 * * *$ & $-5.5524 * * *$ \\
\hline 2 & -0.0037 & -1.1753 & -0.8650 \\
\hline 3 & -0.0029 & -1.5842 & -1.0984 \\
\hline 4 & -0.0081 & $-2.9546^{* *}$ & $-2.3223^{* *}$ \\
\hline 5 & -0.0184 & $-6.8025^{* * *}$ & $-4.5295^{* * *}$ \\
\hline 6 & 0.0046 & $2.9841^{* * *}$ & $1.8439 *$ \\
\hline 7 & 0.0111 & $4.9339 * * *$ & $3.3447^{* * *}$ \\
\hline 8 & 0.0061 & $3.8191^{* * *}$ & $2.8966^{* * *}$ \\
\hline 9 & 0.0152 & $7.4555^{* * *}$ & $4.8835 * * *$ \\
\hline 10 & 0.0229 & $8.6757 * * *$ & $5.6825^{* * *}$ \\
\hline 11 & -0.0118 & $-5.0348 * * *$ & $-4.4484 * * *$ \\
\hline 12 & 0.0025 & 1.2690 & 1.1422 \\
\hline 13 & 0.0071 & $3.3064 * * *$ & $2.5275^{* *}$ \\
\hline 14 & 0.0038 & 1.2819 & 1.2173 \\
\hline 15 & -0.0041 & $-3.2125^{* * *}$ & $-2.8869 * * *$ \\
\hline 16 & -0.0065 & $-3.7718^{* * *}$ & $-3.5589 * * *$ \\
\hline 17 & 0.0080 & $4.6049 * * *$ & $3.6614^{* * *}$ \\
\hline 18 & -0.0034 & $-2.6600 * * *$ & $-2.3278^{* *}$ \\
\hline 19 & -0.0078 & $-3.4373 * * *$ & $-2.4056 * *$ \\
\hline 20 & -0.0016 & -1.5422 & $-1.7308^{*}$ \\
\hline
\end{tabular}

Panel B: Cumulative Abnormal Returns

\begin{tabular}{c|c|c|c}
\hline \hline $\mathrm{t}$ & Abnormal Return & Standard Model & Cross-sectional Model \\
\hline & & $\theta_{1}$ & $\theta_{2}$ \\
\hline CAR $(1,5)$ & -0.0602 & $-4.4847^{* * *}$ & $-5.9252^{* * *}$ \\
\hline CAR $(6,60)$ & 0.0629 & 0.2631 & $2.2539 * * *$ \\
\hline
\end{tabular}


Table 3. (continued)

Panel C: Multivariate Regression Model

\begin{tabular}{c|c|c|c|c|c}
\hline \hline \multicolumn{3}{c|}{ SUR model } & \multicolumn{3}{c}{ Portfolio model } \\
\hline Variable & gamma & H1: F-value & Variable & Gamma & H2: t-value \\
\hline$\gamma_{1}$ & $-0.0290^{* * *}$ & 12.52 & $\gamma_{p 1}$ & $-0.0361^{* * *}$ & -6.09 \\
\hline$\gamma_{2}$ & $-0.0095^{* * *}$ & 7.59 & $\gamma_{p 2}$ & $-0.0104 * * *$ & -3.35 \\
\hline$\gamma_{3}$ & $0.0012^{* *}$ & 1.71 & $\gamma_{p 3}$ & 0.0014 & 1.55 \\
\hline & & & $\mathrm{R}^{2}$ & 0.6621 & \\
\hline
\end{tabular}

* The null hypothesis is rejected at a significance level of $10 \%$, ** Idem, $5 \%$, *** Idem, $1 \%$.

information hypothesis and the overreaction hypothesis predict price reversals, but the uncertain information hypothesis predicts stronger reversals for stocks with higher risk increases, whereas the overreaction hypothesis predicts stronger reversals for higher information asymmetry stocks. If high information asymmetry firms tend to experience higher increase in risk, these two hypotheses are difficult to disentangle. Fortunately, the correlation between volatility changes and information asymmetry proxies are all insignificant except the correlation between $\operatorname{CAR}(2,5)$ and number of analysts. Therefore, it seems that the aforementioned disentanglement issue is not a significant concern in this study.

\section{Abnormal Returns and Cumulative Abnormal Returns Results}

The abnormal returns and cumulative abnormal returns are shown in Table 3. Daily abnormal returns and test statistics using the market model parameter estimation period of $(61,310)$ are presented. Although I re-estimate the abnormal returns using the post-shock period estimation period, I find that insurance company stocks experienced negative abnormal returns during the first week of trading after the $9 / 11$, and then bounced up during the second week, consistent with the Cummins and Lewis (2003) results. The multivariate regression model results are also consistent with the standard and cross-sectional model; the coefficients for $D_{1}$ and $D_{2}$ of equation (12) and (13) are significantly negative and the coefficient of $D_{3}$ are positive. These results of abnormal return reversal after adjusting for the systematic risks support the overreaction 
Table 4. Summary Statistics of the Information Asymmetry Portfolios

\begin{tabular}{l|c|c|c|c|c|c}
\hline \multirow{2}{*}{} & \multicolumn{3}{|c|}{$\begin{array}{c}\text { Portfolio by number of analysts } \\
\text { following }\end{array}$} & \multicolumn{3}{c}{ Portfolio by effective spreads } \\
\cline { 2 - 7 } & High IA & $\begin{array}{c}\text { Medium } \\
\text { IA }\end{array}$ & Low IA & High IA & $\begin{array}{c}\text { Medium } \\
\text { IA }\end{array}$ & Low IA \\
\hline ASSET (\$MM) & $6,525.14$ & $15,725.14$ & $51,882.05$ & $3,931.37$ & $25,749.72$ & $43,552.08$ \\
\hline CAP & $33.97 \%$ & $32.84 \%$ & $31.49 \%$ & $34.73 \%$ & $31.54 \%$ & $32.94 \%$ \\
\hline ANAL & 0.5 & 5.12 & 19.81 & 4.29 & 5.8 & 18 \\
\hline ESPREAD & $1.14 \%$ & $0.37 \%$ & $0.23 \%$ & $1.39 \%$ & $0.32 \%$ & $0.08 \%$ \\
\hline BEST & 15.45 & 12.26 & 11.38 & 14.95 & 12.43 & 11.52 \\
\hline LINE & $20.11 \%$ & $26.56 \%$ & $21.80 \%$ & $21.87 \%$ & $27.61 \%$ & $16.60 \%$ \\
\hline Num. of stocks & 22 & 34 & 26 & 21 & 40 & 21 \\
\hline
\end{tabular}

hypothesis.

In order to strengthen the argument that this reversal is associated with overreaction, I briefly check the correlation between $\operatorname{AR}(1)$ and $\operatorname{CAR}(6,60)$ and the correlation between $\operatorname{CAR}(1,5)$ and $\mathrm{CAR}(6,60)$. If the abnormal return reversal appeared here is an overreaction, the stocks had more negative returns should also bounce up more. Therefore, the correlation between first negative returns and the followed positive returns should be correlated. I find that the corr $(\operatorname{AR}(1), \operatorname{CAR}(6,60))$ is -0.61 and $\operatorname{corr}(\operatorname{CAR}(1,5), \operatorname{CAR}(6,60))$ is -0.50 . That is, stocks had more negative abnormal returns earned more positive abnormal returns during the following period, which supports reversals and overreactions.

\section{Information Asymmetry Portfolio Return Comparison Results}

Given the reversal found in the previous section, now I provide further evidence that this reversal is associated with investors' overreactions. Since the overreaction hypothesis predicts stronger overreactions among high information asymmetry stocks, the abnormal returns and cumulative abnormal returns of information asymmetry portfolios are compared. The summary statistics of portfolios are presented in Table 4 , and the comparison results are showed in Table 5 and Fig. 3.

Consistent with the overreaction hypothesis, AR(1) of the high information asymmetry portfolios is more negative, and $\operatorname{CAR}(6,60)$ 
Table 5. Cumulative Abnormal Return Comparison

\begin{tabular}{|c|c|c|c|c|c|}
\hline & \multicolumn{5}{|c|}{ Subgroup by ESPREAD } \\
\hline & High & Medium & Low & High-Low & T-stat \\
\hline $\operatorname{AR}(1)$ & $-3.51 \%$ & $-3.74 \%$ & $-0.81 \%$ & $-2.69 \% * *$ & -2.08 \\
\hline $\operatorname{CAR}(2,5)$ & $-4.90 \%$ & $-3.19 \%$ & $-0.53 \%$ & $-4.37 \%$ & -1.54 \\
\hline $\operatorname{CAR}(6,60)$ & $18.15 \%$ & $4.24 \%$ & $-2.28 \%$ & $20.42 \% * * *$ & 2.80 \\
\hline$\gamma_{1 \mathrm{k}}$ & -0.0460 & -0.0386 & -0.0154 & $-0.03061^{* * *}$ & 10.31 \\
\hline$\gamma_{2 \mathrm{k}}$ & -0.0156 & -0.0119 & -0.0051 & $-0.0105^{* * *}$ & 4.47 \\
\hline$\gamma_{3 \mathrm{k}}$ & 0.0026 & 0.0012 & 0.0001 & $0.0026^{* * *}$ & 3.12 \\
\hline REV1 & $34.33 \%$ & $17.39 \%$ & $8.49 \%$ & $25.83 \% * * *$ & 3.22 \\
\hline REV2 & $33.94 \%$ & $16.96 \%$ & $7.85 \%$ & $26.09 \% * * *$ & 3.21 \\
\hline \multirow[t]{3}{*}{ REV3 } & $26.90 \%$ & $11.80 \%$ & $5.08 \%$ & $21.82 \% * * *$ & 3.03 \\
\hline & \multicolumn{5}{|c|}{ Subgroup by Number of Analysts } \\
\hline & High & Medium & Low & High-Low & T-stat \\
\hline $\operatorname{AR}(1)$ & $-3.21 \%$ & $-3.23 \%$ & $-2.30 \%$ & $-0.91 \%$ & -0.64 \\
\hline CAR(2,5) & $-4.04 \%$ & $-2.58 \%$ & $-2.50 \%$ & $-1.54 \%$ & -0.64 \\
\hline $\operatorname{CAR}(6,60)$ & $14.95 \%$ & $3.34 \%$ & $2.33 \%$ & $12.62 \% *$ & 1.87 \\
\hline$\gamma_{1}$ & -0.0418 & -0.0322 & -0.0316 & -0.0102 & 0.84 \\
\hline$\gamma_{2}$ & -0.0134 & 0.0012 & -0.0085 & -0.0049 & 0.72 \\
\hline$\gamma_{3}$ & 0.0019 & 0.0012 & 0.0009 & 0.0010 & 0.38 \\
\hline REV1 & $28.19 \%$ & $17.82 \%$ & $14.18 \%$ & $14.01 \%$ * & 1.80 \\
\hline REV2 & $27.73 \%$ & $17.41 \%$ & $13.63 \%$ & $14.10 \% *$ & 1.79 \\
\hline REV3 & $22.21 \%$ & $9.15 \%$ & $7.13 \%$ & $15.09 \%$ ** & 1.95 \\
\hline
\end{tabular}

* The null hypothesis is rejected at a significance level of $10 \%$, ** Idem, $5 \%$, *** Idem, $1 \%$

is more positive than those of low information asymmetry portfolios; the $\operatorname{CAR}(6,60)$ difference between a high and low information portfolio is about $20 \%$ in ESPREAD portfolio and $13 \%$ in ANAL portfolio. The coefficients from multivariate regression model and the three reversal variables also show stronger reversals for high information asymmetry portfolio than low information asymmetry portfolio.

The result can be also seen in Fig. 3. In the Fig. 3, it is very clear that the abnormal return of the high information asymmetry 

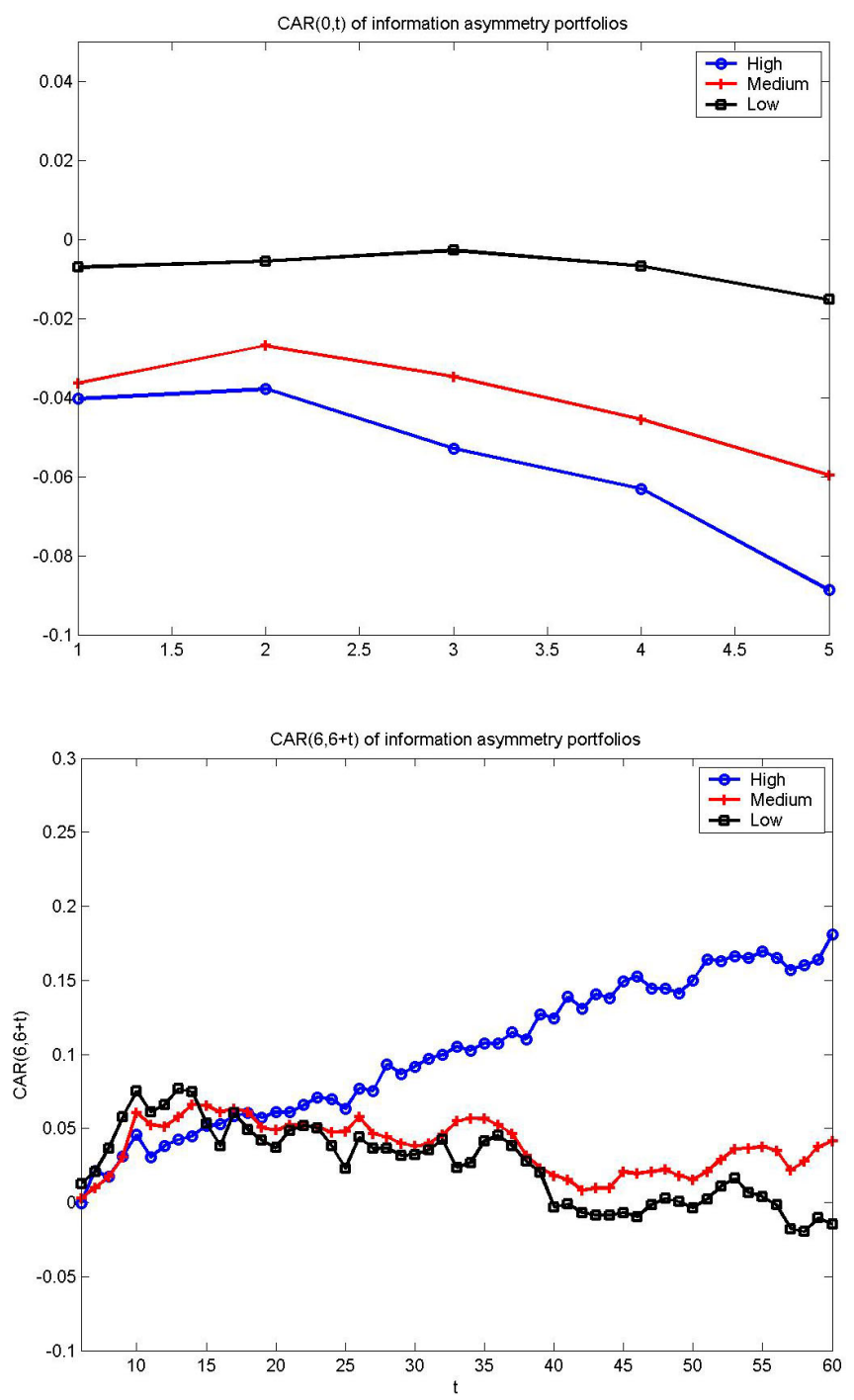

Fig. 3. Cumulative Abnormal Returns of Information Asymmetry Portfolios

portfolio return dropped the most during the first week after the 9/11 attack and the abnormal return of the low information asymmetry portfolio return dropped the least. The cumulative abnormal return graph for the period after the first week of 9/11 also shows very clear difference between different information asymmetry portfolios. The second graph of Fig. 3 shows that the 
CAR of high information asymmetry portfolio increases during the three month period, but the medium and low information asymmetry portfolio does not show strong reversals. It is also worthynote that the low information asymmetry portfolio abnormal returns bounced up earlier than the high information asymmetry portfolio. This is consistent with the hypothesis that arbitragers arbitrage away the more liquid and larger stocks first.

\section{Cross-sectional Regressions Results}

\section{Short-term Cross-sectional Regression Results}

The cross-sectional regression results of the abnormal return on September $17^{\text {th }}$ are shown in Table 6. Column 1 and 2 present regression results with ESPREAD and ANAL as dependent variables, respectively. The regression with $\gamma_{1}$ from the multivariate regression model as dependent variable is also conducted and the result is provided in column 3 .

The overreaction hypothesis predict more negative returns for stocks with greater information asymmetry, and the results are consistent with the hypotheses; the coefficient of ANAL is positive, and ESPREAD is negative.

The significantly negative coefficients of LOSSA indicate that stocks that announced losses had more negative abnormal returns. However, the insignificant coefficients of LOSSP1 imply that the size of announced loss did not have more negative effect on the stock returns. Consistent with the uncertain information hypothesis, the coefficient of VOLC1 is significantly negative, implying that stocks with greater increases in uncertainty had more negative returns. ESC1 is the difference between the effective spread on September $17^{\text {th }}$ and the average ex-ante effective spread, ESPREAD. ESC1 is supposed to capture the information asymmetry increase regarding the 9/11 event; the result of the second regression in the SUR model, shown in Table 8, supports this conjecture.

The uncertainty of the size of the losses was enormous after the 9/11 attack. Insurance companies quickly estimated the losses, and some announced early estimates. However, firms did not release all private information regarding losses and their financial status. Furthermore, many firms had not published their estimates before September $17^{\text {th }}$. Thus, information asymmetry on the loss exposure was also huge. As can be seen in Table 11, stocks with 


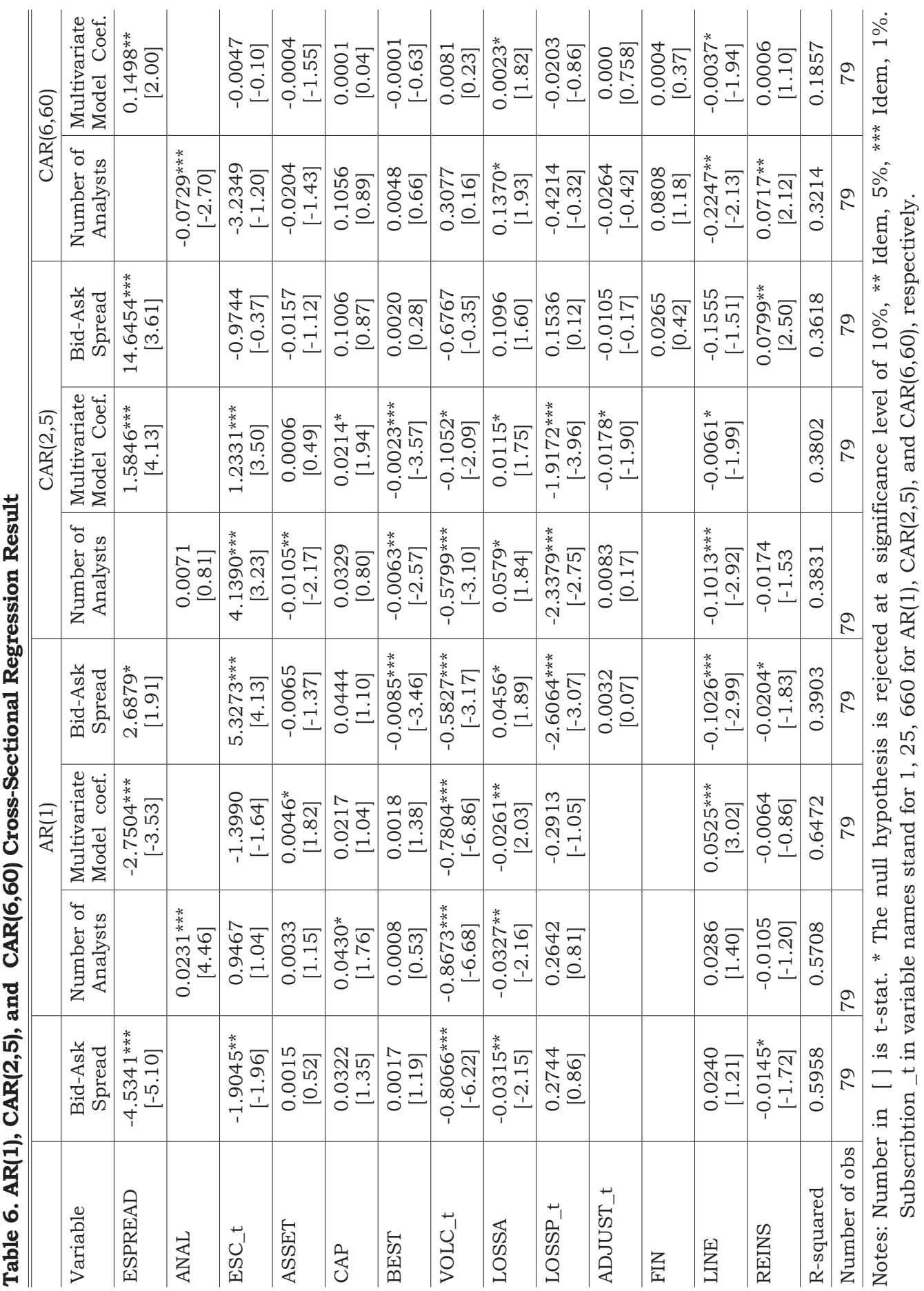


more analysts following had less information asymmetry increase, and the bid-ask spreads increased more if a firm underwrote more on the lines of business experiencing major losses in the 9/11 event. Since some firms shared their private information on loss exposure by announcing the net loss estimates before September $17^{\text {th }}$, the effective spreads of these firms increased less than for the nonannounced firms.

Therefore, the significantly negative coefficients of ESC1 in Table 6 imply that stocks with greater information asymmetry regarding the 9/11 loss had more negative returns. That is, investors penalized the increased information asymmetry since those firms are more likely to be the "lemons" and may show opportunistic behavior with the increased private information. It is also probable that the negative effect of ESC1 is another reflection of the overreaction because ESC1, combined with ESPREAD, captures the overall information asymmetry on September $17^{\text {th }}$.

\section{Long-term Cross-sectional Regression Results}

Column 4-6 of Table 6 presents the regression analysis results with $\operatorname{CAR}(2,5)$ and $\gamma_{2}$ as dependent variables. As more loss estimation information flew into the market, the stock returns were adjusted to the news; the coefficients of LOSSP25 are significantly negative. The negative coefficients of LOSSP25 imply that the newly announced losses during this period were greater than the investors' expectation. The negative effect of LINE may also account for the series of greater-than-expected loss announcements.

Column 7-9 of Table 6 shows the regression results with CAR $(6,60)$ and $\gamma_{3}$ as dependent variables. The results strongly support the overreaction hypothesis. ESPREAD and ANAL are significant in the predicted sign supporting the overreaction hypothesis. For example, the coefficients of ESPREAD are about 15. Since the median ESPREAD of stocks in upper quartile of ESPREAD is about $1.24 \%$ and the median ESPREAD of lower quartile is about $0.08 \%$, the coefficient of 15 means the stocks in upper quartile of ESPREAD gained about $17 \%$ more in terms of abnormal returns during this period compared to the stocks in lower quartile of ESPREAD. Noteworthy is that the ESPREAD and ANAL remains significantly positive even after controlling for the asset size. 
Table 7. Reversal Variables Regression Results

\begin{tabular}{|c|c|c|c|c|c|c|}
\hline & \multicolumn{2}{|c|}{ IREV1 } & \multicolumn{2}{|c|}{ IREV2 } & \multicolumn{2}{|c|}{ IREV3 } \\
\hline ESPREAD & $\begin{array}{c}20.4839^{* * *} \\
{[2.76]}\end{array}$ & $\begin{array}{c}20.1679^{* * *} \\
{[2.74]}\end{array}$ & $\begin{array}{c}20.2788^{* * *} \\
{[2.70]}\end{array}$ & $\begin{array}{c}19.9034^{* * *} \\
{[2.68]}\end{array}$ & $\begin{array}{c}15.8144^{* *} \\
{[2.03]}\end{array}$ & $\begin{array}{c}15.4374 * \\
{[1.99]}\end{array}$ \\
\hline ASSET & $\begin{array}{c}-0.0219^{*} \\
{[-1.70]}\end{array}$ & $\begin{array}{c}-0.0236^{*} \\
{[-1.77]}\end{array}$ & $\begin{array}{c}-0.0242^{*} \\
{[-1.80]}\end{array}$ & $\begin{array}{c}-0.0259^{*} \\
{[-1.87]}\end{array}$ & $\begin{array}{c}-0.0166 \\
{[-1.63]}\end{array}$ & $\begin{array}{c}-0.0176^{*} \\
{[-1.70]}\end{array}$ \\
\hline LOSSA & $\begin{array}{c}0.1578^{* * *} \\
{[2.79]}\end{array}$ & $\begin{array}{c}0.1706^{* * *} \\
{[2.66]}\end{array}$ & $\begin{array}{c}0.1671^{* * *} \\
{[2.90]}\end{array}$ & $\begin{array}{c}0.1807^{* * *} \\
{[2.76]}\end{array}$ & $\begin{array}{c}0.1215^{* *} \\
{[2.52]}\end{array}$ & $\begin{array}{c}0.1301^{* *} \\
{[2.39]}\end{array}$ \\
\hline LOSSP1 & $\begin{array}{c}-0.1909 \\
{[-0.40]}\end{array}$ & $\begin{array}{c}-0.0933 \\
{[-0.10]}\end{array}$ & $\begin{array}{c}-0.1799 \\
{[-0.37]}\end{array}$ & $\begin{array}{c}-0.0075 \\
{[-0.11]}\end{array}$ & $\begin{array}{c}-0.0075 \\
{[-0.02]}\end{array}$ & $\begin{array}{c}-0.0399 \\
{[-0.05]}\end{array}$ \\
\hline LOSSP25 & $\begin{array}{c}-1.7231 \\
{[-0.76]}\end{array}$ & $\begin{array}{c}-2.0250 \\
{[-0.87]}\end{array}$ & $\begin{array}{c}-1.9641 \\
{[-0.78]}\end{array}$ & $\begin{array}{c}-2.2818 \\
{[-0.89]}\end{array}$ & $\begin{array}{c}-1.1548 \\
{[-0.52]}\end{array}$ & $\begin{array}{c}-1.3460 \\
{[-0.59]}\end{array}$ \\
\hline LOSSP660 & $\begin{array}{c}-0.0299 \\
{[-0.38]}\end{array}$ & $\begin{array}{c}-0.0958 \\
{[-1.06]}\end{array}$ & $\begin{array}{c}-0.0418 \\
{[-0.47]}\end{array}$ & $\begin{array}{c}-0.1119 \\
{[-1.10]}\end{array}$ & $\begin{array}{c}0.0091 \\
{[0.12]}\end{array}$ & $\begin{array}{c}-0.0359 \\
{[-0.45]}\end{array}$ \\
\hline ADJUST25 & $\begin{array}{c}-0.0019 \\
{[-0.02]}\end{array}$ & $\begin{array}{c}-0.0217 \\
{[-0.27]}\end{array}$ & $\begin{array}{c}0.0024 \\
{[0.03]}\end{array}$ & $\begin{array}{c}-0.0183 \\
{[-0.22]}\end{array}$ & $\begin{array}{c}-0.0302 \\
{[-0.68]}\end{array}$ & $\begin{array}{c}-0.0423 \\
{[-0.85]}\end{array}$ \\
\hline ADJUST660 & $\begin{array}{c}-0.0572 \\
{[-1.44]}\end{array}$ & $\begin{array}{c}-0.0793 \\
{[-1.57]}\end{array}$ & $\begin{array}{c}-0.0593 \\
{[-1.44]}\end{array}$ & $\begin{array}{c}-0.0829 \\
{[-1.59]}\end{array}$ & $\begin{array}{c}-0.0379 \\
{[-1.06]}\end{array}$ & $\begin{array}{c}-0.0534 \\
{[-1.25]}\end{array}$ \\
\hline FIN & $\begin{array}{c}0.0696^{*} \\
{[1.69]}\end{array}$ & $\begin{array}{c}0.0712 \\
{[1.66]}\end{array}$ & $\begin{array}{c}0.0666 \\
{[1.56]}\end{array}$ & $\begin{array}{c}0.0683 \\
{[1.54]}\end{array}$ & $\begin{array}{c}0.0328 \\
{[1.09]}\end{array}$ & $\begin{array}{c}0.0336 \\
{[1.07]}\end{array}$ \\
\hline LINE & $\begin{array}{c}-0.1495 \\
{[-1.56]}\end{array}$ & $\begin{array}{c}-0.1517 \\
{[-1.62]}\end{array}$ & $\begin{array}{c}-0.1598 \\
{[-1.59]}\end{array}$ & $\begin{array}{c}-0.1613 \\
{[-1.64]}\end{array}$ & $\begin{array}{c}-0.1309 \\
{[-1.63]}\end{array}$ & $\begin{array}{c}-0.1296 \\
{[-1.64]}\end{array}$ \\
\hline REINS & $\begin{array}{c}0.0573^{* *} \\
{[1.90]}\end{array}$ & $\begin{array}{c}0.0534 \\
{[1.57]}\end{array}$ & $\begin{array}{c}0.0581^{* *} \\
{[1.92]}\end{array}$ & $\begin{array}{c}0.0545 \\
{[1.60]}\end{array}$ & $\begin{array}{c}0.0607^{* *} \\
{[2.10]}\end{array}$ & $\begin{array}{c}0.0600 \\
{[1.90]}\end{array}$ \\
\hline VOLMM & $\begin{array}{c}0.3683 \\
{[1.21]}\end{array}$ & & $\begin{array}{c}0.3833 \\
{[1.23]}\end{array}$ & & $\begin{array}{c}0.2158 \\
{[0.76]}\end{array}$ & \\
\hline VOLPRE & & $\begin{array}{c}0.5494 \\
{[0.19]}\end{array}$ & & $\begin{array}{c}0.6654 \\
{[0.22]}\end{array}$ & & $\begin{array}{c}0.7075 \\
{[0.28]}\end{array}$ \\
\hline R-Squared & 0.5049 & 0.4898 & 0.5011 & 0.4853 & 0.4290 & 0.4228 \\
\hline $\begin{array}{l}\text { Number of } \\
\text { obs }\end{array}$ & 79 & 79 & 79 & 79 & 79 & 79 \\
\hline
\end{tabular}

Notes: Number in [ ] is t-stat. * The null hypothesis is rejected at a significance level of $10 \%$, ** Idem, 5\%, *** Idem, 1\%

Reversal Variable Regression Results

Table 7 shows the regression analysis results with REV1, REV2, and REV3 as dependent variables. Column 1, 3, and 5 present the result with the realized volatility change control, and column 2, 4, 
Table 8. Information Asymmetry Change and Uncertainty Change Regression Results

\begin{tabular}{l|c|c|c|c|c|c}
\hline \hline Variable & ESC1 & VOLC1 & ESC25 & VOLC25 & ESC660 & VOLC660 \\
\hline ANAL & $-0.0010^{*}$ & $\begin{array}{c}0.0011 \\
{[-1.69]}\end{array}$ & $\begin{array}{c}0.0020^{* * *} \\
{[4.03]}\end{array}$ & $\begin{array}{c}0.0063^{* * *} \\
{[3.76]}\end{array}$ & $\begin{array}{c}0.0014 \\
{[1.29]}\end{array}$ & $\begin{array}{c}-0.0017 \\
{[-1.24]}\end{array}$ \\
\hline CAP & $\begin{array}{c}-0.0051^{*} \\
{[-1.62]}\end{array}$ & $\begin{array}{c}0.0167 \\
{[0.70]}\end{array}$ & & & & \\
\hline ESC $\tau_{1}$ & & & $0.8907^{* * *}$ & & $0.8002^{* * *}$ & \\
& & & {$[11.03]$} & & {$[4.07]$} & \\
\hline VOLC $\tau_{1}$ & & & & $0.9518^{* * *}$ & & $0.2876^{* *}$ \\
& & & & {$[25.25]$} & & {$[2.71]$} \\
\hline LOSSA $\tau_{1}$ & $-0.0029^{*}$ & $0.0309^{* * *}$ & -0.0010 & -0.0062 & 0.0009 & -0.0050 \\
& {$[-1.92]$} & {$[2.66]$} & {$[-0.67]$} & {$[-1.22]$} & {$[0.35]$} & {$[-1.37]$} \\
\hline ADJUST $\tau_{1}$ & & & 0.0006 & -0.0007 & -0.0031 & -0.0038 \\
& & & {$[-0.19]$} & {$[-0.06]$} & {$[-1.36]$} & {$[-1.14]$} \\
\hline FIN & & & & & 0.0014 & -0.0006 \\
& & & & & {$[0.51]$} & {$[-0.16]$} \\
\hline LINE & 0.0036 & 0.0261 & $0.0037^{* *}$ & 0.0061 & $-0.0090^{* * *}$ & -0.0064 \\
& {$[1.60]$} & {$[1.52]$} & {$[2.11]$} & {$[0.97]$} & {$[-2.70]$} & {$[-1.44]$} \\
\hline REINS & -0.0086 & 0.0011 & 0.0009 & $0.0067^{* * *}$ & $0.0030^{* *}$ & -0.0019 \\
& {$[-0.98]$} & {$[0.16]$} & {$[1.21]$} & {$[2.69]$} & {$[2.18]$} & {$[-0.16]$} \\
\hline R-squared & 0.1585 & 0.1897 & 0.4978 & 0.8802 & 0.3051 & 0.1621 \\
\hline Number of & 79 & 79 & 79 & 79 & 79 & 79 \\
obs & & & & & & \\
\hline
\end{tabular}

Notes: Number in [ ] is t-stat. * The null hypothesis is rejected at a significance level of $10 \%$, ** Idem, $5 \%$, *** Idem, $1 \%$

and 6 show the same regression result with pre-shock volatility level control. The results in this model is also support the overreaction hypothesis; coefficients of ESPREAD is more than 15 and significant. This means the stocks in upper quartile of ESPREAD bounced up about $17 \%$ more in terms of abnormal returns during this three month period compared to the stocks in lower quartile of ESPREAD.

\section{CONCLUSION AND DISCUSSION}

In this paper, I examine the stock price reactions to the $9 / 11$ 
terrorist attack to find evidence of investors' overreaction. Behavior finance models and psychology literature predict that investors overreact to a salient and extreme event, and the degree of overreactions would be greater among high information asymmetry stocks.

I find evidence that investors overreacted to $9 / 11$; significantly negative abnormal returns on the first day of trading are followed by significant positive abnormal returns. In addition, the reversals are found to be stronger among high information asymmetry stocks, where the bid-ask spreads and the number of analysts following a stock are used as proxies of information asymmetry.

The reversals may be attributed to the systematic risk and uncertainty changes. However, this does not seem to be the case in this study since the abnormal returns are obtained using the market parameters computed with the post-shock estimation period returns, and the results remain robust after controlling for uncertainty changes. Furthermore, the risk changes are not positively correlated with the level of information asymmetry. Therefore, the results of this paper suggest that the market shows evidence of overreactions that is likely to be related to the market inefficiency.

Alternative explanation to the result of this paper is that it is probably the analysts who overreacted. There is some evidence that analysts' reaction to the 9/11 shocks could rationally explain shortrun return reversal in New York REITs markets (Kallberg, Liu, and Pasquariello, 2008). Analysts' expectation dynamically changes under semistrong market efficiency during the post-9/11 time period.

\section{REFERENCES}

Andersen, T. G., T. Bollerslev, F. X. Diebold, and H. Ebens (2001), The Distribution of Realized Stock Return Volatility. Journal of Financial Economics, 61(1):43-76.

Andersen, T. G., T. Bollerslev, F. X. Diebold, and P. Labys (2003), Modeling and Forecasting Realized Volatility. Econometrica, 71(2):579-625.

Barberis, N., A. Shleifer, and R. Vishny (1998), A Model of Investor Sentiment. Journal of Financial Economics, 49:307-343.

Barry, C. B. and S. J. Brown (1985), Differential Information and Security Market Equilibrium. The Journal of Financial and Quantitative Analysis, 
20(4):407-422.

Bhagat, S., J. A. Brickley, and U. Loewenstein (1987), The Pricing Effects of Interfirm Cash Tender Offers. Journal of Finance, 42(4):965-986.

Brennan, M. J. and A. Subrahmanyam (1995), Investment Analysis and Price Formation in Securities Markets. Journal of Financial Economics, 38(3):361-381.

Brown, K. C., W. V. Harlow, and S. M. Tinic (1988), Risk Aversion, Uncertain Information, and Market Efficiency. Journal of Financial Economics, 22(2):355-385.

Brown, K. C., W. V. Harlow, and S. M. Tinic (1993), The Risk and Required Return of Common Stock following Major Price Innovations. The Journal of Financial and Quantitative Analysis, 28(1):101-116.

Clarkson, P. M. and R. Thompson (1990), Empirical Estimates of Beta When Investors Face Estimation Risk. Journal of Finance, 45(2):431-453.

Coles, J. L. and U. Loewenstein (1988), Equilibrium Pricing and Portfolio Composition in the Presence of Uncertain Parameters. Journal of Financial Economics, 22(2):279-303.

Coles, J. L., U. Loewenstein, and J. R. Suay (1995), On Equilibrium Pricing under Parameter Uncertainty. Journal of Financial and Quantitative Analysis, 30(3):347-364.

Cummins, J. D. and C. Lewis (2003), Catastrophic Events, Parameter Uncertainty and the Breakdown of Implicit Long-Term Contracting: The Case of Terrorism Insurance. Journal of Risk and Uncertainty, 26(2/3):153-178.

Daniel, K., D. Hirshleifer, and A. Subrahmanyam (1998), Investor Psychology and Security Market Over- and Under-reaction. Journal of Finance, 53:1839-1886.

DeJong, D. V. and D. W. Collins (1976), Explanations for the Instability of Equity Beta: Risk-Free Rate Changes and Leverage Effects. The Journal of Financial and Quantitative Analysis, 20(1):73-94.

DeJong, D. V. and D. W. Collins (1976), Explanations for the Instability of Equity Beta: Risk-Free Rate Changes and Leverage Effects. The Journal of Financial and Quantitative Analysis, 20(1):73-94.

Doherty, N., J. Lamm-Tennant, and L. T. Starks (2003), Insuring September 11th: Market Recovery and Transparency. The Journal of Risk and Uncertainty, 26(2/3):179-199.

Doherty, N. and L. L. Posey (1997), Availability Crises in Insurance Markets: Optimal Contracts with Asymmetric Information and Capacity Constraints. Journal of Risk and Uncertainty, 15:55-80.

Drakos, K. (2004), Terrorism-Induced Structural Shifts in Financial Risk: Airline Stocks in the Aftermath of the September 11th Terror Attacks. European Journal of Political Economy, 20:435-446.

Fama, E. F. (1998), Market Efficiency, Long-term Returns, and Behavioral 
Finance. Journal of Financial Economics, 49:283-306.

Galai, D. and R. W. Masulis (1976), The Option Pricing Model and the Risk Factor of Stock. Journal of Financial Economics, 3(1-2):53-81.

Gleason, C. A. and C. M. C. Lee (2003), Analyst Forecast Revisions and Market Price Discovery. Accounting Review, 78(1):193-225.

Griffin, D. and A. Tversky (1992), The Weighing of Evidence and the Determinants of Confidence, Cognitive Psychology. Journal of Risk and Uncertainty, 24(3):411-435.

Hirshleifer, D. (2001), Investor Psychology and Asset Pricing. The Journal of Finance, 56(4):1533-1597.

Kalay, A. and U. Loewenstein (1985), Predictable Events and Excess Returns: The Case of Dividend Announcements. Journal of Financial Economics, 14(3):423-450.

Kallberg, J., C. Liu, and P. Pasquariello (2008), Updating expectations: An analysis of post-9/11 returns. Journal of Financial Markets, 11(4): 400432.

Lang, M. H. and R. J. Lundholm (1996), Corporate Disclosure Policy and Analyst Behavior. Accounting Review, 71(4):467-492.

Zhang, F. (2006). Information Uncertainty and Stock Returns. Journal of Finance, 6(1):105-137.

Received September 13, 2018

Accepted October 11, 2018 
APPENDIX I. LIST OF COMPANIES IN THE SAMPLE

\begin{tabular}{|c|c|c|}
\hline $\begin{array}{c}\text { Acceptance Insurance } \\
\text { Co Inc }\end{array}$ & ACE Ltd & AEGON N.V. \\
\hline AFLAC Inc & Alfa Corp & Allstate Corp \\
\hline $\begin{array}{l}\text { American Financial } \\
\text { Group Inc }\end{array}$ & AIG & $\begin{array}{l}\text { American National } \\
\text { Insurance Co }\end{array}$ \\
\hline $\begin{array}{l}\text { American Physicians } \\
\text { Capital }\end{array}$ & $\begin{array}{l}\text { American Safety Ins } \\
\text { Holdings }\end{array}$ & AmerUs Group Co \\
\hline Arch Capital Group Ltd & Argonaut Group Inc & Atlantic American Corp \\
\hline Baldwin and Lyons Inc & Bancinsurance Corp & Berkshire Hathaway Inc \\
\hline Ceres Group Inc & Chubb Corp & $\begin{array}{l}\text { Cincinnati Financial } \\
\text { Corp }\end{array}$ \\
\hline CNA Financial Corp & Commerce Group Inc & $\begin{array}{l}\text { Cotton States Life } \\
\text { Insurance Co }\end{array}$ \\
\hline Donegal Group Inc & $\begin{array}{l}\text { EMC Insurance Group } \\
\text { Inc }\end{array}$ & Erie Indemnity Co \\
\hline Everest Re Group Ltd & $\begin{array}{l}\text { FPIC Insurance Group } \\
\text { Inc }\end{array}$ & Gainsco Inc General \\
\hline $\begin{array}{l}\text { Hanover Insurance } \\
\text { Group Inc }\end{array}$ & Harleysville Group Inc & $\begin{array}{l}\text { Hartford Fin Svcs Group } \\
\text { Inc }\end{array}$ \\
\hline $\begin{array}{l}\text { HCC Insurance Holdings } \\
\text { Inc }\end{array}$ & $\begin{array}{l}\text { Horace Mann Educators } \\
\text { Corp }\end{array}$ & Jefferson-Pilot Corp \\
\hline $\begin{array}{l}\text { Kansas City Life } \\
\text { Insurance Co }\end{array}$ & Lincoln National Corp & Manulife Financial Corp \\
\hline Markel Corp & $\begin{array}{l}\text { Meadowbrook Ins Group } \\
\text { Inc }\end{array}$ & Merchants Group Inc \\
\hline Mercury General Corp & Metlife Inc & Midland Co \\
\hline MIIX Group Inc & National Security Group & $\begin{array}{l}\text { National Western Life } \\
\text { Ins Co }\end{array}$ \\
\hline Navigators Group Inc & NCRIC Group Inc & NYMAGIC Inc \\
\hline Ohio Casualty Corp & $\begin{array}{l}\text { Old Republic } \\
\text { International Corp }\end{array}$ & PartnerRe Ltd \\
\hline $\begin{array}{l}\text { Penn Treaty American } \\
\text { Corp }\end{array}$ & Penn-America Group Inc & $\begin{array}{l}\text { Philadelphia Cons } \\
\text { Holdings }\end{array}$ \\
\hline PMA Insurance Group & Presidential Life Corp & ProAssurance Corp \\
\hline
\end{tabular}




\begin{tabular}{l|l|l}
\hline \hline \multicolumn{1}{c|}{$\begin{array}{c}\text { Acceptance Insurance } \\
\text { Co Inc }\end{array}$} & \multicolumn{1}{|c}{ ACE Ltd } & \multicolumn{1}{c}{ AEGON N.V. } \\
\hline Progressive Corp & Protective Life Corp & PXRE Group Ltd \\
\hline RLI Corp & Royal and Sun Alliance & Safeco Corp \\
\hline SCPIE Holdings Inc & $\begin{array}{l}\text { Selective Insurance } \\
\text { Group Inc }\end{array}$ & St Paul Cos Inc \\
\hline $\begin{array}{l}\text { StanCorp Financial } \\
\text { Group Inc }\end{array}$ & State Auto Financial & Sun Life Financial Inc \\
\hline Trenwick Group Ltd & United Fire and Casualty & Unitrin Inc \\
\hline Universal American Corp & Unum Group & Vesta Insurance Group \\
\hline $\begin{array}{l}\text { White Mountains Ins } \\
\text { Group }\end{array}$ & WR Berkley Corp & XL Capital Ltd \\
\hline $\begin{array}{l}\text { Zenith National } \\
\text { Insurance Corp }\end{array}$ & & \\
\hline
\end{tabular}

